\title{
Late Pleistocene stratigraphy, glaciation chronology and Middle Weichselian environmental history from Klintholm, Møn, Denmark
}

\author{
MICHAEL HOUMARK-NIELSEN
}

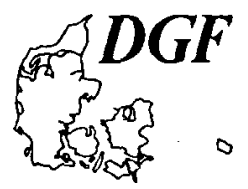

\begin{abstract}
Houmark-Nielsen, M.: Late Pleistocene stratigraphy, environmental history and Middle Weichselian glaciation chronology from Klintholm, Møn, Denmark. Bulletin of the Geological Society of Denmark, Vol 41, pp. 181-202. Copenhagen, 1994-11-30. https://doi.org/10.37570/bgsd-1995-41-16
\end{abstract}

A new and fundamental outline of the Late Pleistocene geological history in SE Denmark is obtained from examination of exposed cliff sections along the Baltic coast of Møn. Multidiciplinary studies including lithostratigraphic classification, analyses of glaciotectonic structures, biostratigraphic studies, amino acid chronology and radiocarbon and luminescence dating indicate the following:

A shallow boreo-lusitanian sea that characterized the Eemian interglaciation (130-115 ka BP) was followed by periglacial conditions during the Early Weichselian (115-75 ka BP). In the early part of the Middle Weichselian (75-c. $40 \mathrm{ka} \mathrm{BP}$ ) Baltic glaciers invaded the region twice, intemupted by an ice free and periglacial interval around $50 \mathrm{ka}$ BP. The first ice stream left a reddish coloured till dominated by exotic rock-types of eastern Baltic provenance. From about $40-35 \mathrm{ka} \mathrm{BP}$ to slightly before $20 \mathrm{ka} \mathrm{BP}$ ameliorated conditions with periglacial terrestrial and lacustrine environments are recorded. A lake basin in the western part of the Baltic was surrounded by a low releif mammoth-steppe with an almost treeless vegetation of grasses, sedges, heather and dwarf shrubs. Increasing amounts of diamicton dominated by Palaeozoic shale and limestone towards the top of the muddy and slightly organic lake sediments suggest ice-rafting in the basin by the end of the late Middle Weichselian. Deposits suffered strong glaciotectonic deformation during the Late Weichselian glacial maximum (25-15 ka BP).

Michael Houmark-Nielsen, Geological Institute, University of Copenhagen, Østervoldgade 10, DK-1350, Copenhagen K. 1st March, 1994.

\section{Introduction and background}

During the last couple of decades much new evidence has been published on the course of Late Pleistocene glaciations and the history of climate, vegetation and marine environments in Southwest Scandinavia. Recent stratigraphical achievements and long time established chronologies exist for the Late Weichselian, i.e. 10-25 ka BP. During this period Denmark experienced the complex Main-Weichselian glaciation from 25 to about $14 \mathrm{ka}$ BP (Jylland stade, Houmark-Nielsen 1989) followed by the Late Glacial climatic amelioration including the interstadial Bølling-Allerød oscillation (13-11 ka BP), finally leading to the interglacial conditions that characterize the Holocene (Hansen 1965).

For the Middle- and Early Weichselian, fairly extensive and well documented biostratigraphic records have been reported from regions outside the reach of Weichselian glaciers (Andersen 1961, Behre \& Lade 1986, Griiger 1989). However, in most of the circum-Baltic region and Southwest Scandinavia, geological evidence on the last interglacial/glacial cycle is fragmentary and often conflicting. The sparsity of stratigraphic evidence is generally due to re-sedimentation under periglacial conditions and glaciotectonic dislocation during multiglacial stages of the Weichselian. The poverty of information may also be due to the fact that several interstadial and stadial phases with highly similar biota lie at the limit or beyond the safe reach of radiocarbon dating and succeeded each other during the Weichselian without leaving significant biostratigraphical or age dependent fingerprints (Ran 1990, Kolstrup 1992).

Radiocarbon dates of Middle Weichselian flora and fauna fragments are reported from several sites in Southwest Scandinavia and summarized by Houmark-Nielsen (1989) and Aaris-Sørensen, Petersen \& Tauber (1990). The obtained ages have largely been taken at face value even though reports of unexpected radiocarbon ages have been published, some of which can be ascribed to contamination by younger carbon (Lykke-Andersen 1982, 


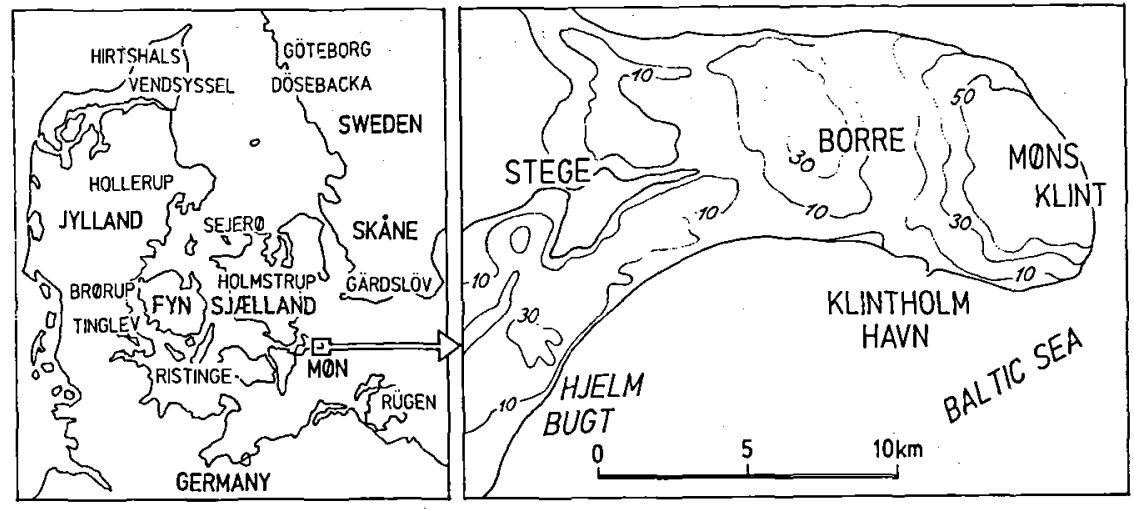

Fig. 1. Key and location map of Møn with names mentioned in the text.

Lagerlund \& Houmark-Nielsen 1993); others show enigmatic discrepancies between the palaeoecologic settings and ${ }^{14} \mathrm{C}$ ages (Kolstrup 1991, 1992, Steinich 1992).

Several Late Pleistocene stratigraphic units in Denmark have been dated by the thermoluminescence method (Kronborg 1984, Kronborg \& Mejdahl 1989, Petersen \& Kronborg 1991), though with varying and sometimes questionable results. As demonstrated by Mejdahl, Shlukov, Shakhovets, Voskovskaya \& Lyashenko (1992), conventional TL (thermoluminescence) and OSL (optically stimulated luminescence) dates may be underestimated by as much as $30 \%$. Dreimanis, Hütt, Raukas \& Whippey (1985) stated that, apart from sunlight, postdepositional zeroing of the TL signal may be affected by groundwater circulation and they also cited the effect of pressure and friction. Mejdahl (1988) discussed to what degree insufficient bleaching may be accounted for. Moreover, Forman (1990) indicated that different depositional environments allow different amounts of exposure to sunlight.

The combination of fragmentary stratigraphic and palaeo-environmental records together with available radiocarbon and luminescence dates have lead to the proposal of several event stratigraphic models (Berthelsen 1979, Petersen 1984, Houmark-Nielsen 1987, 1989). Special attention has been paid to the possible age of a postEemian Baltic glaciation in Denmark occurring prior to the Late Weichselian maximum.

Arguments in favour of an Early to Middle Weichselian (pre $40 \mathrm{ka} \mathrm{BP}$ ) glaciation are given by Petersen (1984) and summarized and extended in Petersen \& Kronborg (1991). Mainly based on TL dates of supposed melt-water sand, till and soil profiles from central Jylland (Kronborg, Bender, Bjerre, Friborg, Jacobsen, Kristiansen, Rasmussen, Sørensen \& Larsen 1990), it is suggested that most of Denmark was covered by Baltic glacier ice between 70 and $60 \mathrm{ka}$ BP. The authors support this view by (1) the presence of Baltic till beneath middle Weichselian marine deposits at Holmstrup, Sjælland, (2) finds of twigs of Juniperus of Middle Weichselian age on the Tinglev sandur, southern Jylland and (3) ice-rafted glacial debris of supposed Baltic origin in the Middle Weichselian marine sequences at Vendsyssel.

Unfortunately, all TL dates presented by Kronborg et al 1990 and Petersen \& Kronborg (1991) are given without reference to Ris $\emptyset$ laboratory numbers thus preventing assessment of technical aspects and laboratory data. A re-evaluation of the published dates, including age corrections after the recommendations of Mejdahl et al. (1992), suggests deposition of postulated glacigenic sediments during the Early Weichselian around the time of the Brørup interstade (100 ka BP) or shortly after. Nevertheless the possible relation of these deposits to the glaciation in question has previously been debated (Dansk geologisk Forening 1990) and persistently questioned by Houmark-Nielsen (1990a, b).

Houmark-Nielsen (1987) regarded the age of a preMain Weichselian ice stream as an open question, even though data from Sejerø suggest Baltic ice cover over eastern Denmark sometime between 35 and $20 \mathrm{ka}$ BP. It was stated that the arguments in favour of an age older than the Hengelo interstadial ( $>35 \mathrm{ka} \mathrm{BP}$ ) were insufficient, especially due to the lack of biostratigraphic and geochronological support. The present paper intends to present new stratigraphic and palaeo-environmental evidence supplemented by a series of radiocarbon and evaluated luminescence dates corrected after the recommendations of Mejdahl et al. (1992). The results of recent palaeontological studies on the Klintholm sections (Kolstrup \& Houmark-Nielsen 1991, Bennike, Heiberg \& Houmark-Nielsen 1993, Bennike, Houmark-Nielsen, Böcher \& Heiberg 1994) have added substantial new evidence on the history of Middle Weichselian terrestrial palaeoecology and it is integrated and summarized in the present paper.

To confirm the basic framework of glaciation chronology presented by Houmark-Nielsen (1989) in a palaeogeographical interpretation of the Weichselian history and to provide solid stratigraphic support for Petersen's (1984) hypothesis on the possible age of a Weichselian glaciation prior to $36 \mathrm{ka} \mathrm{BP}$, this paper will bring new information of regional significance from key sites in the 
Klintholm area, Møn (Fig. 1). It is the aim of this work to demonstrate correspondence between sedimentary sequences in the cliff sections around Klintholm and to present composite stratigraphic data in a readily accessible form. Knowledge on the development of sedimentary environments and biota along with glaciation chronology around Klintholm are used to outline a geological history that has consequences for larger parts of the circum-Baltic region with special reference to Middle Weichselian events (75-25 ka BP). The data and conclusions of this work lead to an extended outline of Middle Weichselian geological history. This includes till deposition during two glaciations followed by ice-free lacustrine and terrestrial environments characterized by an arctic-subarctic flora and fauna and the deposition of slightly organic mud, sand-loess and possible ice-rafted diamict material into a lake basin in the western Baltic region.

\section{Previous investigations}

Systematic counts of provenance dependent Fennoscandian and Baltic rock fragments in beach gravels along cliffs of eastern Møn show a strong domination of Baltic and Åland types over Dalarian rocks indicating deposition by glaciers from the Baltic region (Milthers 1942). The apparent absence of rock types with a more westerly provenance suggests that most Late Pleistocene glaciers reached M $\varnothing$ n through the Baltic depression.

Stratigraphic studies at Møns Klint east of Klintholm (Fig. 1) indicate that two tills interbedded with shellbearing sand and pebbly diamict mud can be ascribed to the Weichselian (Hintze 1937; Konradi 1973; Berthelsen 1981, 1986). Along with the underlying Cretaceous chalk, Pleistocene deposits underwent strong and multiple glaciotectonic deformation by the Main (Northeast) and the Young Baltic advance during the Late Weichselian maximum (Berthelsen 1986). A simplified model, proposing that only the last Young Baltic re-advance contributed to the tectonic layout of Møns Klint, was given by Jensen (1993). The relations between tectonic setting and geomorphic features of Møn were demonstrated by Hintze (1937), Haarsted (1956) and Aber (1985).

West of Klintholm in Hjelm Bugt (Fig. 1), pebbly diamict mud and several tills along with marine deposits of the Eemian are found in a strongly glaciotectonized state (Berthelsen, Konradi \& Petersen 1977; Aber 1979). The glaciotectonic displacement of Quaternary deposits and rafts of chalk are associated with the retreat of the Late Weichselian Northeast ice stream and readvances of the Young Baltic ice from southeasterly directions (Berthelsen et al. 1977).

On the evidence of macrofossil contents Ødum (1933) suggested correlation between marine interglacial deposits on Møn, Rügen and Sjælland with parts of the Eemian and Weichselian marine sequence at Skærumhede, Vend- syssel. This correlation was revised by Konradi (1973) who indicated that the interglacial marine foraminiferal faunas found in the so called Cyprina clay along the present Baltic coast of Denmark including Møn and Sjælland corresponds to the Eemian interglaciation. This is supported by analyses of amino acid ratios of marine shells in the region (Miller \& Mangerud 1986).

The Quaternary sequences of Kobbelgård and Kraneled around Klintholm (Fig. 2) were preliminarily presented by. Houmark-Nielsen $(1988,1990$ a) in an attempt to demonstrate correspondance between marker beds at the two cliff sites.

A restricted part of the cliff site at Kobbelgård (site 2 in this paper) containing organic material was described in detail by means of lithostratigraphy and palynology supported by radiocarbon and TL dates (Kolstrup \& Houmark-Nielsen 1991). It was concluded that pollen-bearing muddy and slightly organic lake sediments with bedded diamictons and aeolian sand and silt were deposited between 30 and $20 \mathrm{ka} \mathrm{BP}$. Even though much redeposited plant material occurs, pollen studies point towards an almost treeless, subarctic heath and shrub vegetation and it was suggested that the lake deposits may contain plant detritus of both Middle and Early Weichselian age. The vegetational fingerprint and absolute ages from the younger part of the sequence are compared with previously described late Middle Weichselian sites from Dösebacka (Hillefors 1974) and Gärdslöv (Miller 1977) in southern Sweden as well as sites from the Hartz Mountains in northern Germany (Steinmüller 1967).

Bennike et al. $(1993,1994)$ reported on the macro flora and fauna of the same stratigraphic units that were subjected to pollen studies and found remnants of a subarctic flora and fauna including the first reliable finds of lemmings in Denmark.

\section{Methods}

Cross sections, showing major stratigraphic units from coastal cliff exposures respectively east and west of Klintholm (Fig. 2), were drawn as seen from the beach using field observations and photographs (Figs 3 and 4). The orientation of glaciotectonic structures was measured and added to the cross sections.

Ten individual sites (Fig. 2) were chosen for the compilation of lithostratigraphic logs (Fig. 5). Units are described after the scheme adopted by Houmark-Nielsen (1987) and are characterized by grain size, sedimentary structures, fossil contents, clast fabrics and petrography of diamictons and their boundaries to adjacent units including glaciotectonic unconformities. The locations of individual sites are shown in Figs 3 and 4. Samples taken in connection with the present investigation are indicated on the logs as well as the stratigraphic range of series of samples taken for microfossil analyses. A synthesis of data is given in Fig. 15.

Modified fine gravel analyses after the Dutch method 


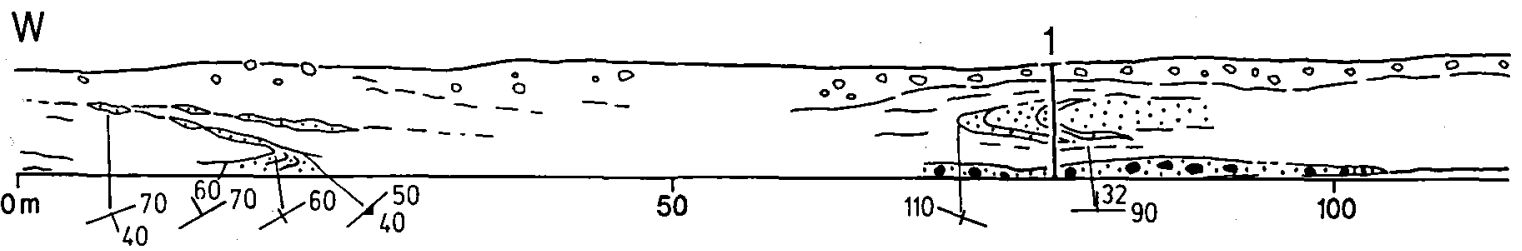

$3 \mathrm{~A}$

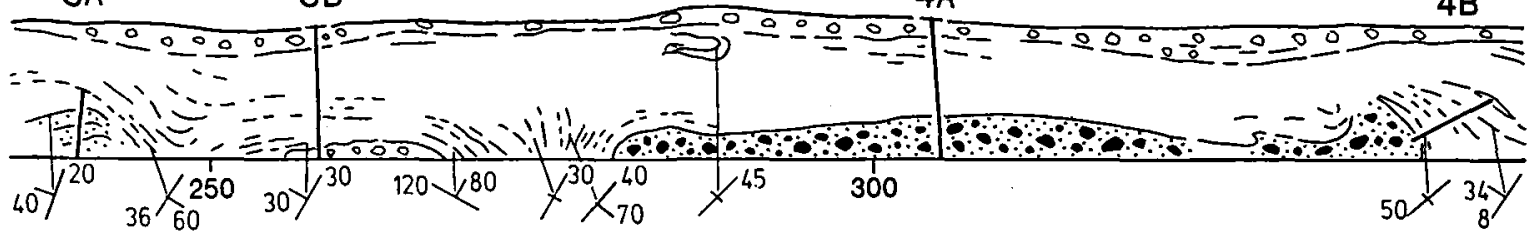

(Ehlers 1979) were made in order to characterize individual diamict units and to correlate these both on a local and regional scale. Selected stratigraphic units were analysed for evidence of flora and fauna in order to add palaeoecological information to the sedimentary environments. Alloisoleucine:isolleucine $(\mathrm{D} / \mathrm{L})$ epimerization of marine mollusc shells was measured in order to correlate with other marine deposits in the region that has been subjected to aminoacid analyses. ${ }^{14} \mathrm{C}$ and luminescence dating was made to give estimates on ages of fossils and sediments and to relate deposits to the Late Pleistocene chronostratigraphy.
The complex data sets from the Klintholm sections are presented in a stratigraphic data chart (Fig. 15) after the outline of Houmark-Nielsen \& Berthelsen (1981) and Houmark-Nielsen (1987). The data chart combines lithostratigraphy, glaciotectonic deformation characteristics, clast fabric analyses, petrographic fine gravel counts, macrofossil studies and modified pollen and foraminifera data combined with amino acid ratios, radiocarbon and luminescence dates. Environmental interpretations, major events including the course of glaciations and a chronostratigraphic subdivision are added to the chart.



Fig. 2. Location of the Kobbelgård and Kraneled sections, Møn. Numbers refer to examined sites $(1-10)$. Contour interval $5 \mathrm{~m}$. 



Fig. 3. Cross section of coastal cliff exposures, Kobbelgård. Numbers 1-4 indicate locations of lithostratigraphic logs. No exaggeration of scale.

\section{Late Pleistocene stratigraphy of the Klintholm sections}

The sections around Klintholm comprise coastal cliff exposures where a total of nine lithostratigraphic units have been identified. Sections are situated about 2.5 to 3 $\mathrm{km}$ west of Klintholm Havn (Kobbelgård section, Fig. 2) and between 1 and $2.2 \mathrm{~km}$ east of Klintholm Havn (Kraneled section, Fig. 2).

The c. $400 \mathrm{~m}$ long Kobbelgård section exposes units 6-8 most often in a strongly glaciotectonized state, whereas unit 9 locally and unconformably overlies the deformed sediments (Fig. 3). Structures comprise open to recumbent folds and overthrusts generated by glaciotectonic deformation of an ice stream that overrode the area. Sites 1-4 were chosen for lithostratigraphic logging.

The cliff section at Kraneled is about $1 \mathrm{~km}$ long and shows consistent exposures in the central and eastern part (Fig. 4). Units 1-3 and smaller rafts of chalk are in places heavily disturbed by glaciotectonic stacking and folding and unconformably overlain by units 4-8 which appear in a much less glaciotectonized condition than at Kobbelgård. Unit 9 often comprises a stony boulder lag draping the cliff section. In the western part of the Kraneled section units 7 and 8 have been thrusted and isoclinally folded by an overriding glacier from the southeast. Sites 5-10 were chosen for lithostratigraphic logging. The de- formational chronology as seen in the data chart (Fig. 15) indicates that glaciotectonic deformation from the southeast and the east took place immediately prior to deposition of unit 4 and that deposition of unit 9 was accompanied by strong glaciotectonic deformation from southeasterly directions.

\section{Lithostratigraphy}

Ten lithostratigraphic logs were measured from exposures along the cliff sites (Fig. 5). Simple and composite logs represent sedimentary sequences comprising diamictons, marine sand and mud (clay - silt), solifluction material, fluvial deposits, lacustrine sediments and sand loess that has been exposed over the last 5 years. On the basis of lithic characters and boundary conditions and stratigraphic position, nine lithostratigraphic units have been identified.

\section{Unit descriptions}

\section{Saalian till}

Unit 1 is a grey, chalk-banded matrix-supported diamicton less than $2 \mathrm{~m}$ in thickness and found at sites 8 and 10 (Figs $5 \& 15$ ). Towards the top diamict beds are 

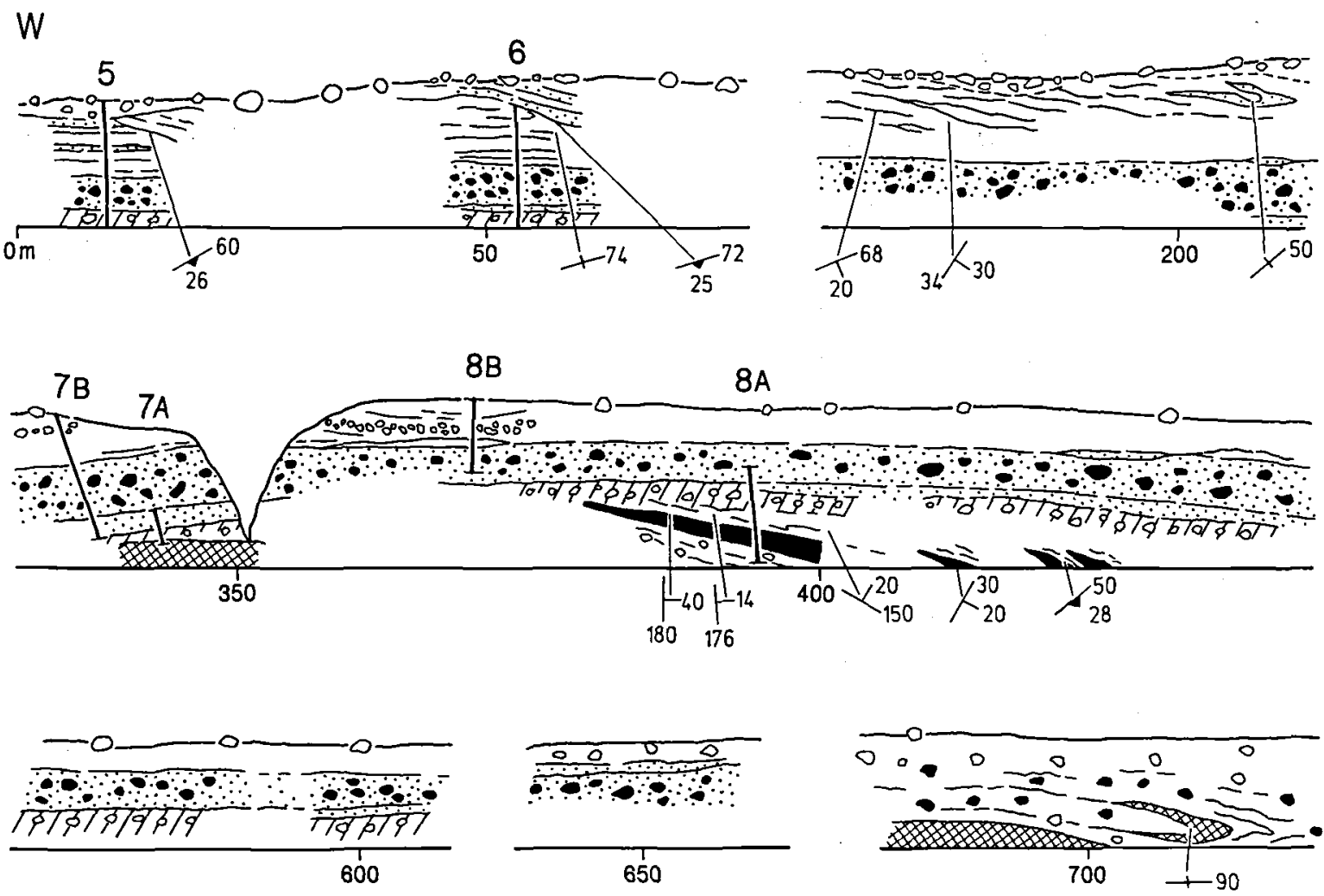

intercalated with waterlain mud. Clast composition shows domination of crystalline rocks and Palaeozoic limestone and shale with minor quantities of local rock types such as chalk and flint (samples 1-5, Fig. 15). The diamicton is interpreted as a till deposited by a glacier from the Baltic that invaded the area before the Eemian most probably during the late Saalian, based on its similarity with the Lillebælt Till (Houmark-Nielsen 1987).

\section{Marine interglacial deposits}

Unit 2 comprises glaciotectonically thrusted shell-bearing bluish-grey mud and grey sand found at sites 8 and 10 (Figs 5, 6 \& 15). Deposits are less than $2 \mathrm{~m}$ in thickness and rich in marine molluscs such as Arctica islandica, Turritella communis, Nassa reticulata and minor quantities of Cardium edule, Littorina obtusata and Macoma baltica. Unit 2 is gradually overlain by unit 3 and has an indistinct boundary to unit 1 . Foraminiferal analyses were made in the interglacial sequence and parts of the adjointing units (Kristensen 1993). Studies of the upper 30 $\mathrm{cm}$ of the marine deposits show the presence of a boreolusitanian shallow water fauna with a very low content of redeposited and pre-Quaternary species (Fig. 15, F). The foraminiferal assemblage from Klintholm is comparable to marine faunas of the last interglaciation found around the western Baltic and North sea (Konradi 1976; Knudsen 1985, 1991; Penny 1989). Even though the uppermost sample of the marine sequence indicates colder conditions, it is concluded that unit 2 most probably was deposited during the Eemian interglaciation in a shallow water $(<20 \mathrm{~m})$ environment changing from fresh water to marine conditions with temperatures and salinity slightly higher than at present (Kristensen 1993).

\section{Solifluction and fluvial deposits}

Unit 3 comprises up to $3 \mathrm{~m}$ of bluish-grey to brown muddy, crudely bedded sediment gravity flows composed of diamicton, sand lenses and discontinuous beds of mud with marine molluscs overlying marine sediments (sites $7,8 \& 10$, Figs 5, $6 \& 15$ ). Cross-bedded sand and gravel with frost-cracked flint pebbles and intraclasts of marine clay also occur in unit 3 (site 10). The two facies contain whole shells and fragments from a fauna similar to the Eemian. Unit 3 is interpreted as solifluction and fluviallacustrine sediments deposited under periglacial conditions after the Eemian and prior to the first Weichselian ice advance. 

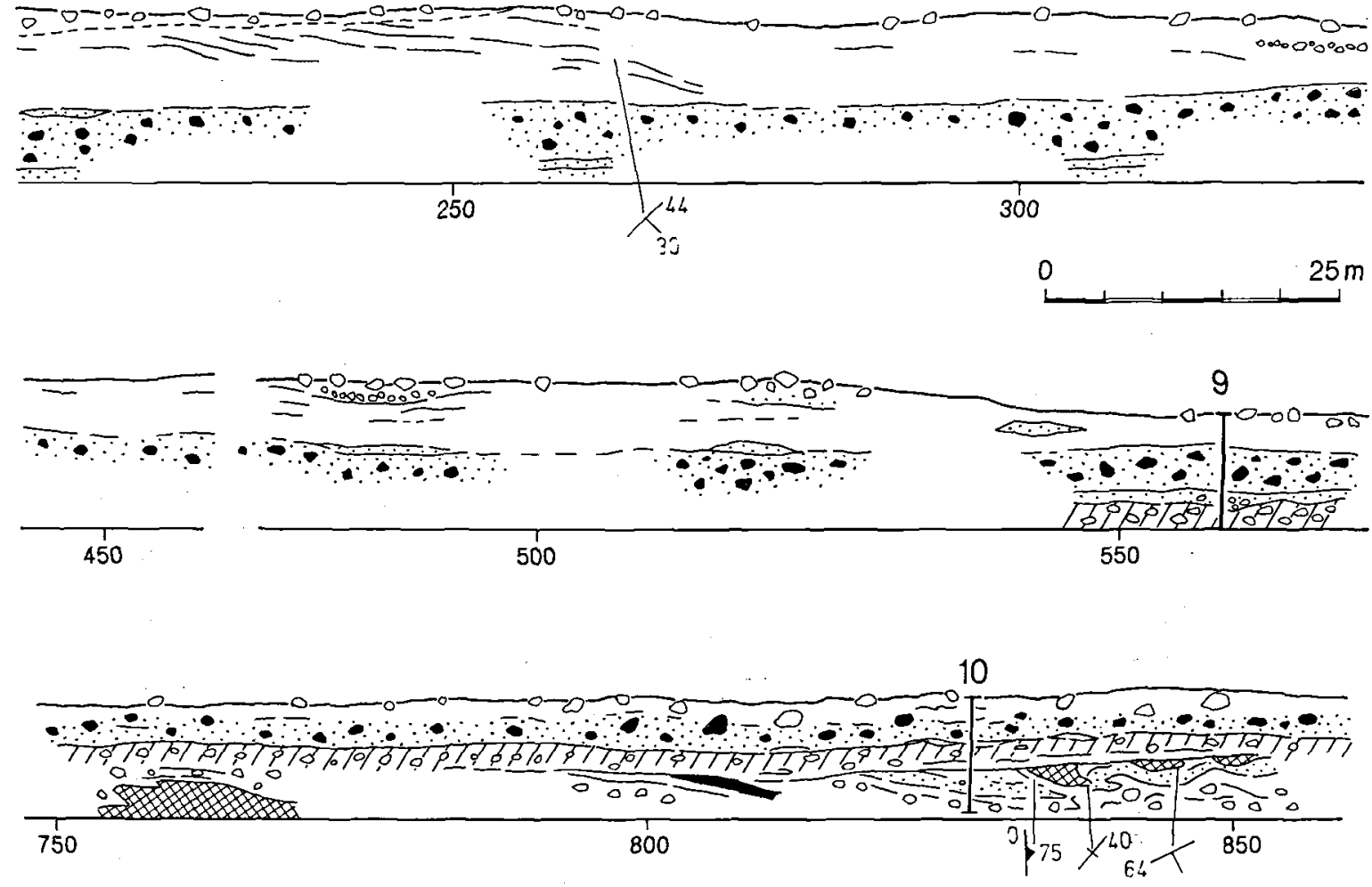

Fig. 4. Cross section of coastal cliff exposures, Kraneled. Numbers 5-10 indicates location of lithostratigraphic logs. No exaggeration of scale. Legend see Fig. 3.

\section{Grey-red till}

The above mentioned stratigraphic units and smaller rafts of Cretaceous chalk have been strongly glaciotectonized due to deformation by a glacier that overrode the area from southeasterly and easterly directions (sites $8 \& 10$, Figs $5,7 \& 15$ ).

The deformed beds are unconformably overlain by a $\mathrm{c}$. $2 \mathrm{~m}$ thick crudely banded, muddy and sandy, grey and reddish matrix-supported diamicton covered by fluvial sand and gravel (sites 5-10, Figs 5, $8 \& 15$ ). In the lower part the banding is composed of sheared and folded lenses of chalk or sand with redeposited marine shells, while in the upper part it consists of smeared reddish sand and sandstones. Fabric analyses show a strong and preferred orientation towards the southeast (F1 and F6, Fig. 15). Fine gravel composition reflects the change in colour of the diamicton (samples 6-15; Fig. 15). The lower, grey part shows a mixture of local rock sources (flint and chalk) and fragments of far-travelled Baltic Palaeozoic limestone, shale and sandstone. The upper reddish part is totally without local material and is dominated by Baltic erratics of Palaeozoic limestone and sandstone. By far the majority of sandstones are reddish and they are possibly the source of the colour in the upper part of the diamicton.
Unit 4 is interpreted as a till bed deposited by a glacier moving through the Baltic depression locally from the southeast and the east as indicated by glacio-tectonic structures beneath the till and by its clast fabric orientation. The change in clast composition and colour may reflect rock debris transported in different levels of the glacier, far-travelled erratics being concentrated in the upper parts (cf. Ehlers 1992).

\section{Glaciofluvial and lacustrine deposits}

Unit 5 comprises an up to $3 \mathrm{~m}$ thick fining upwards sequence with a sharp and erosive boundary to the reddish till and in most cases with a thin but gradual and non-erosive transition to the overlying diamicton (Figs 5, $8 \& 15)$.

The lower part of unit 5 is composed of cross-bedded and imbricate clast-supported coarse gravel with a sandy and often reddish matrix that cuts the surface of the red till. Fine gravel counts in parts of this unit indicate erosion of the two provenance dependent facies of the underlying diamicton (samples 16-17; Fig. 15). At site 7, an involuted horizon is found in the gravel (Fig. 9). The upper part of unit 5 found at sites 5 to $\mathbf{1 0}$ is built up of cross-bedded gravel and sand succeeded by beds of fine sand and laminated mud. 


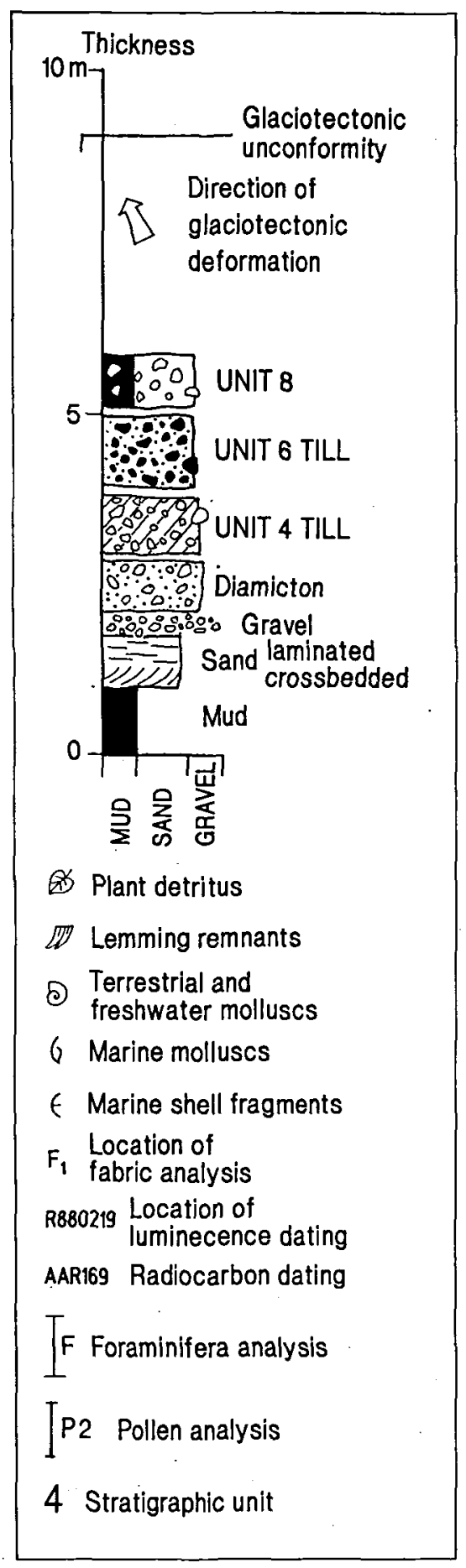

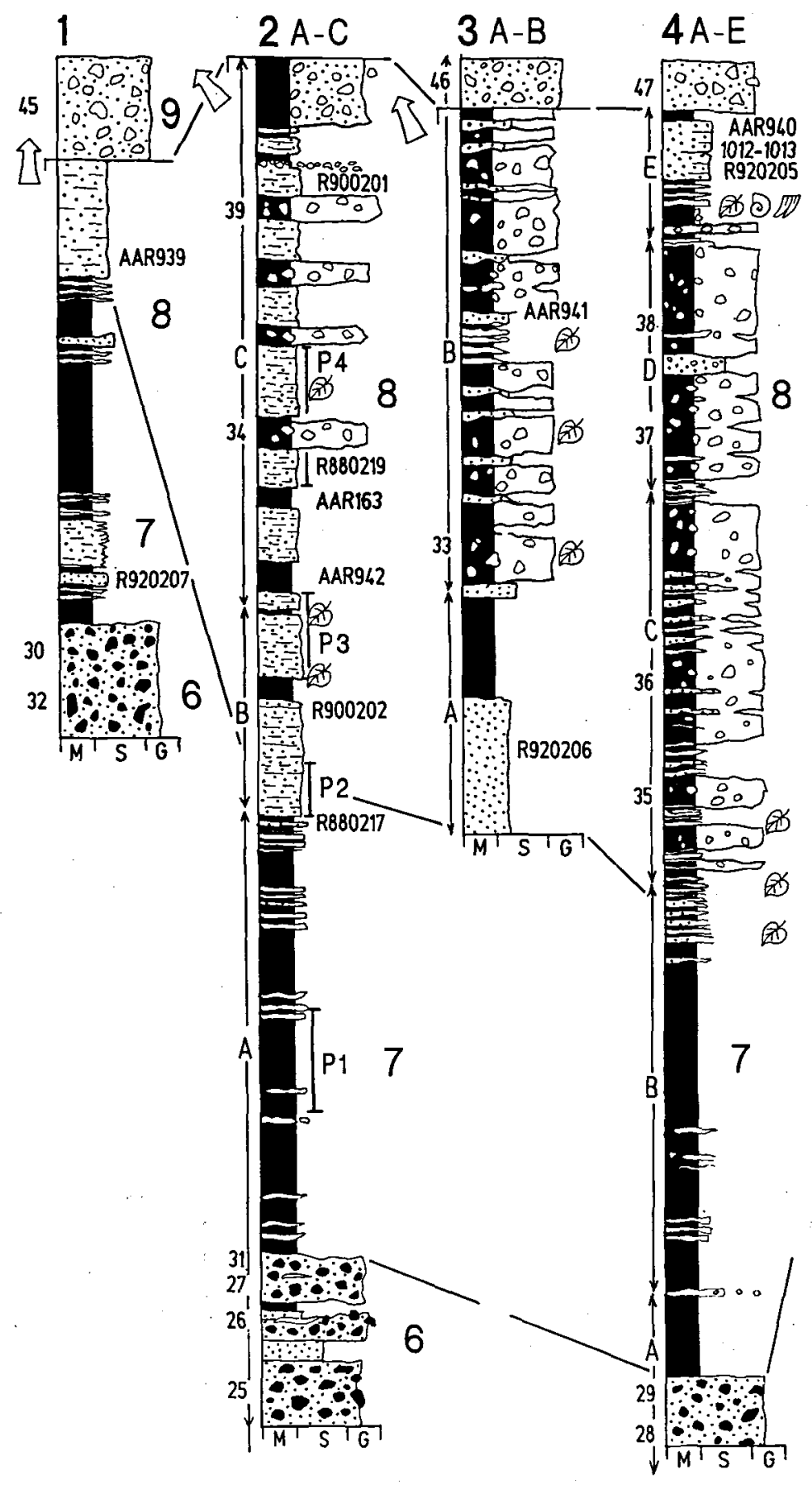

Fig. 5. Simple and composite lithostratigraphic logs, Kobbelgård (left) and Kraneled (right). 


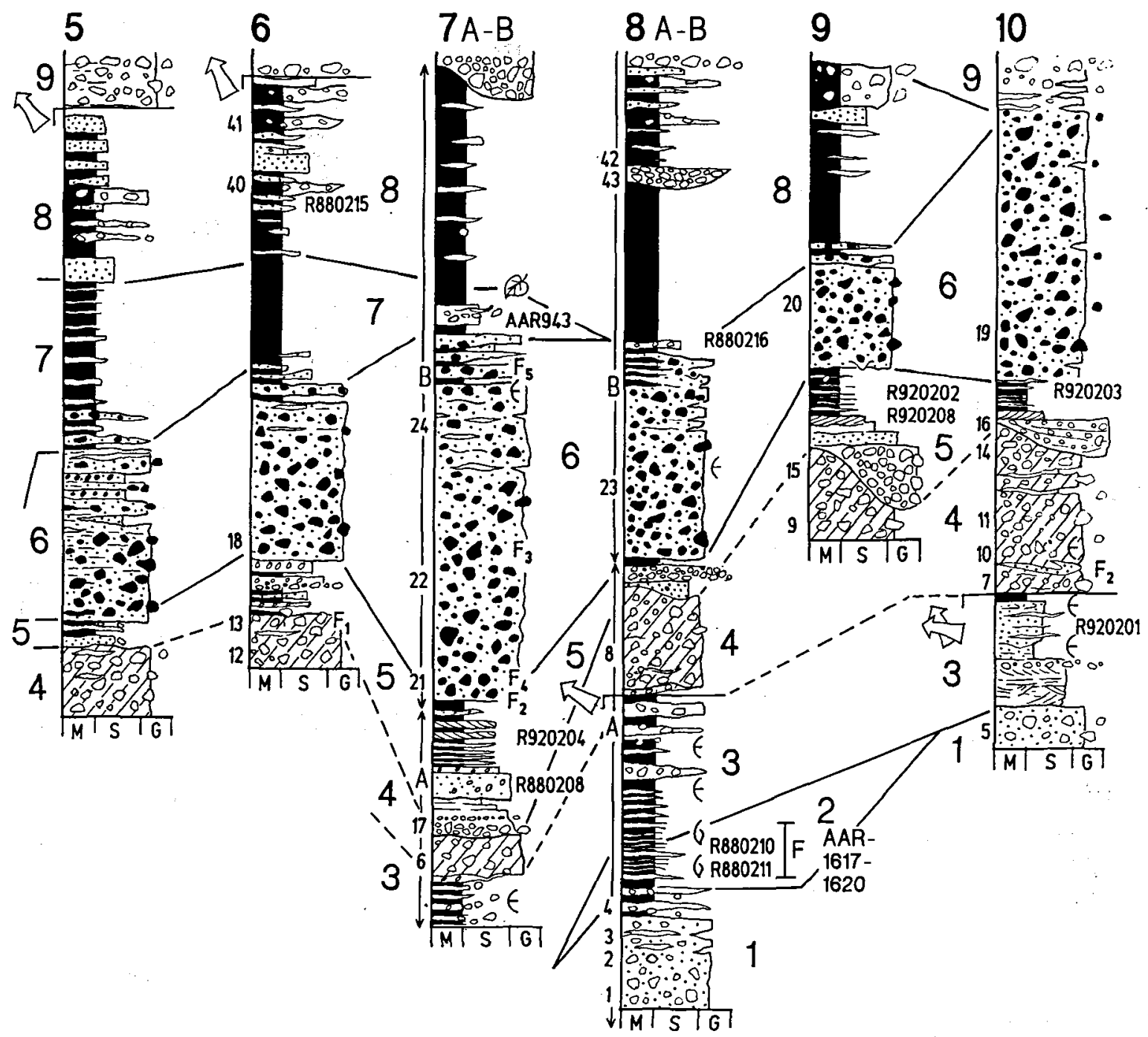

Unit 5 signals a change from glaciofluvial conditions to a low energy, possibly lacustrine, environment suggesting a rise in water level. Sedimentation may have ceased during a phase of periglacial activity causing involutions in gravel beds.

\section{Thick grey diamicton}

Unit 6 is a more than $4 \mathrm{~m}$ thick grey muddy and sandy matrix supported diamicton (sites 1-2, 4 and 5-10; Figs $5,10 \& 15$ ). It has a indistinct and non-erosive lower boundary of about $10 \mathrm{~cm}$ in thickness gradually changing from laminated mud to pebbly diamicton (Figs 8 and 9). At the uppper boundary, the diamicton is interbedded with increasing amounts of crudely laminated lenses of sand and mud, forming a gradual c. $1 \mathrm{~m}$ thick upward transition to lacustrine sediments (Fig. 10). Fabric analyses show a somewhat random clast orientation, but with a concentration in an northwest - southeast direction at some levels (F2 - F5, Fig. 15). The diamicton occasionally contains redeposited shells or shell fragments from the marine Eemian deposits. Fine gravel counts show a Baltic clast composition with a mixture of local rock sources (samples 18-32; Fig. 15).

Unit 6 is interpreted as a till which was deposited by an ice stream moving through the Baltic depression. The lower transition from a lacustrine to a subglacial environment suggests glacier movement in a water filled basin. Long axis orientations give no clear indication of direction of ice movement; in fact, fabrics may suggest melting in a subaqueous setting for parts of the till. 


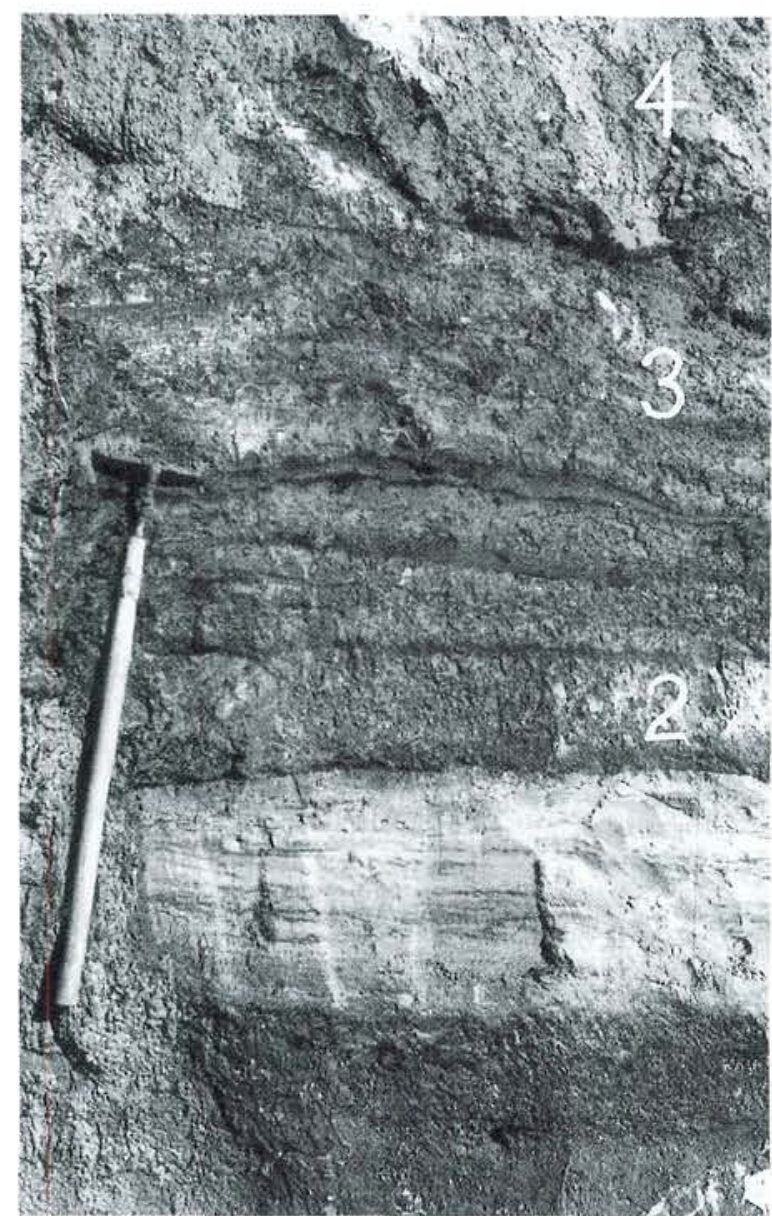

Fig. 6. Marine Eemian clay and sand (unit 2) overlain by solifluction material (unit 3 ) and till (unit 4), site 8 . Handle is $0.5 \mathrm{~m}$.

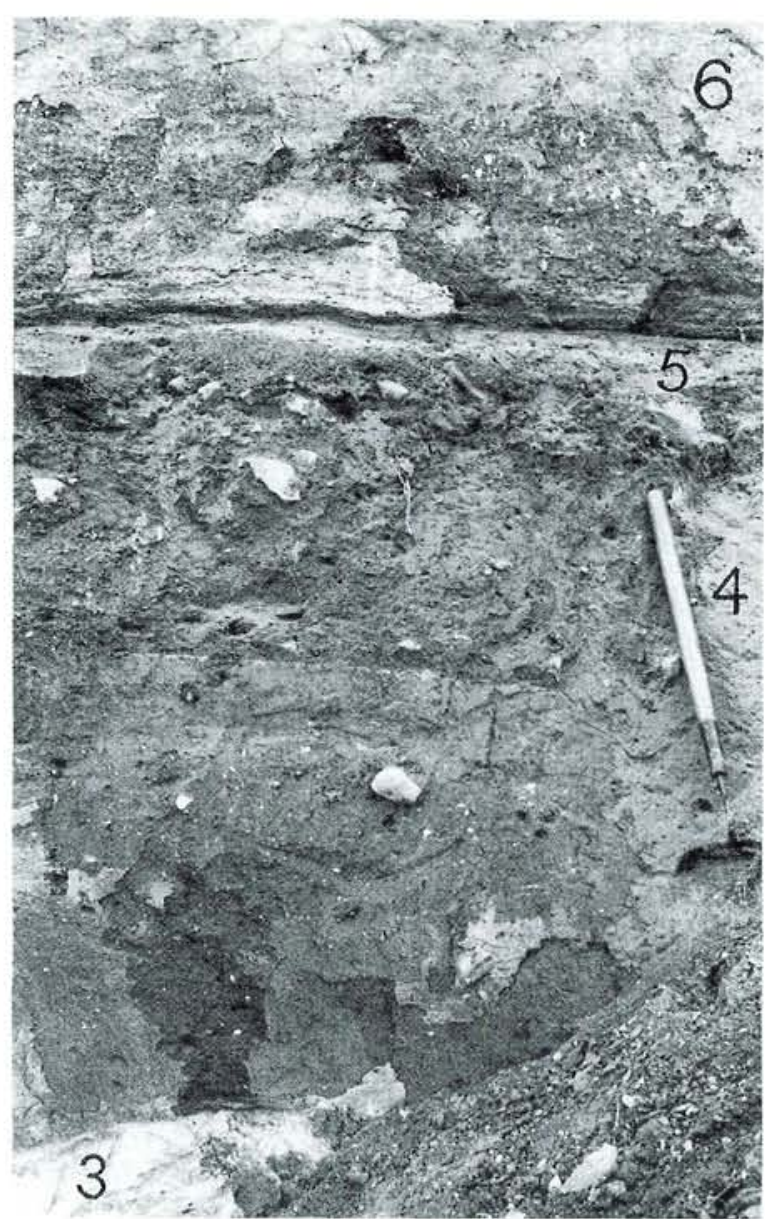

Fig. 8. Grey-red till (unit 4) overlying redeposited marine sand (unit 3 ) and covered by sand and mud (unit 5) and grey till (unit 6), site 10 . Handle is $0.5 \mathrm{~m}$.

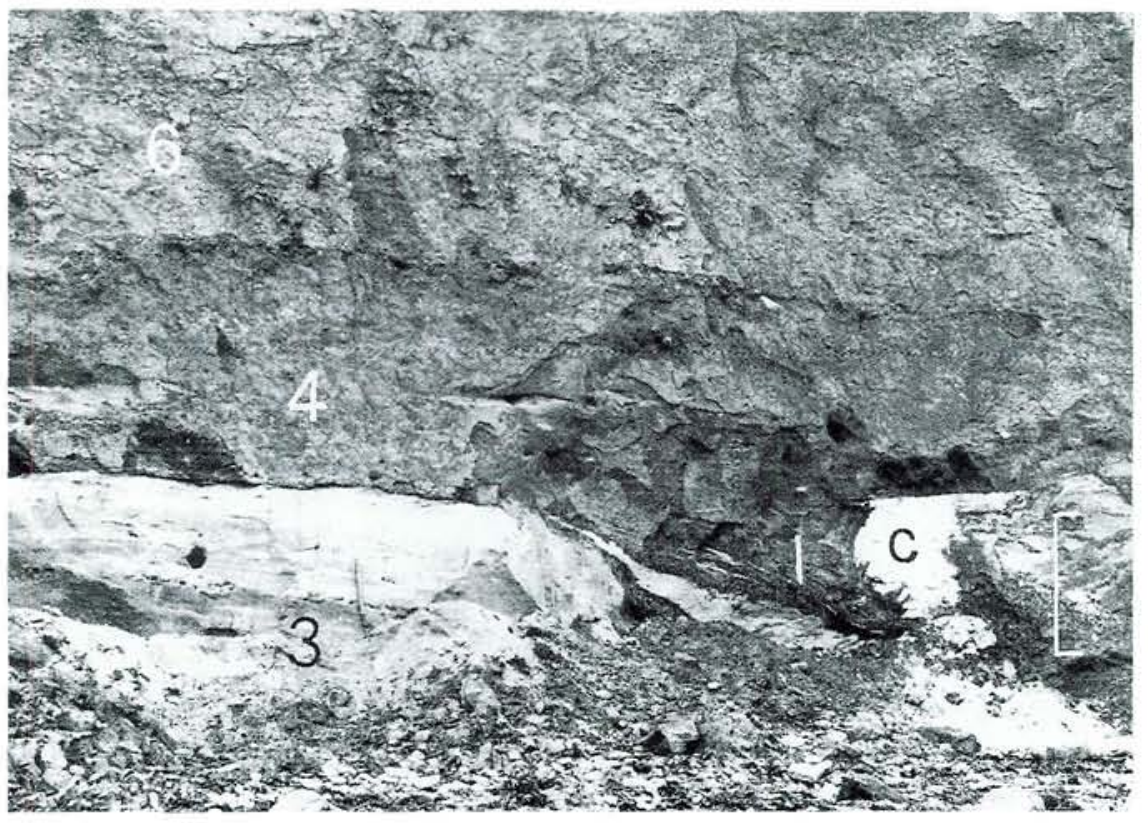

Fig. 7. Strongly disturbed redeposited marine sand (unit 3), older till (unit 1) and chalk (C) overlain by two till beds (units 4 and 6 ), site 10 . Scale is $1 \mathrm{~m}$. 


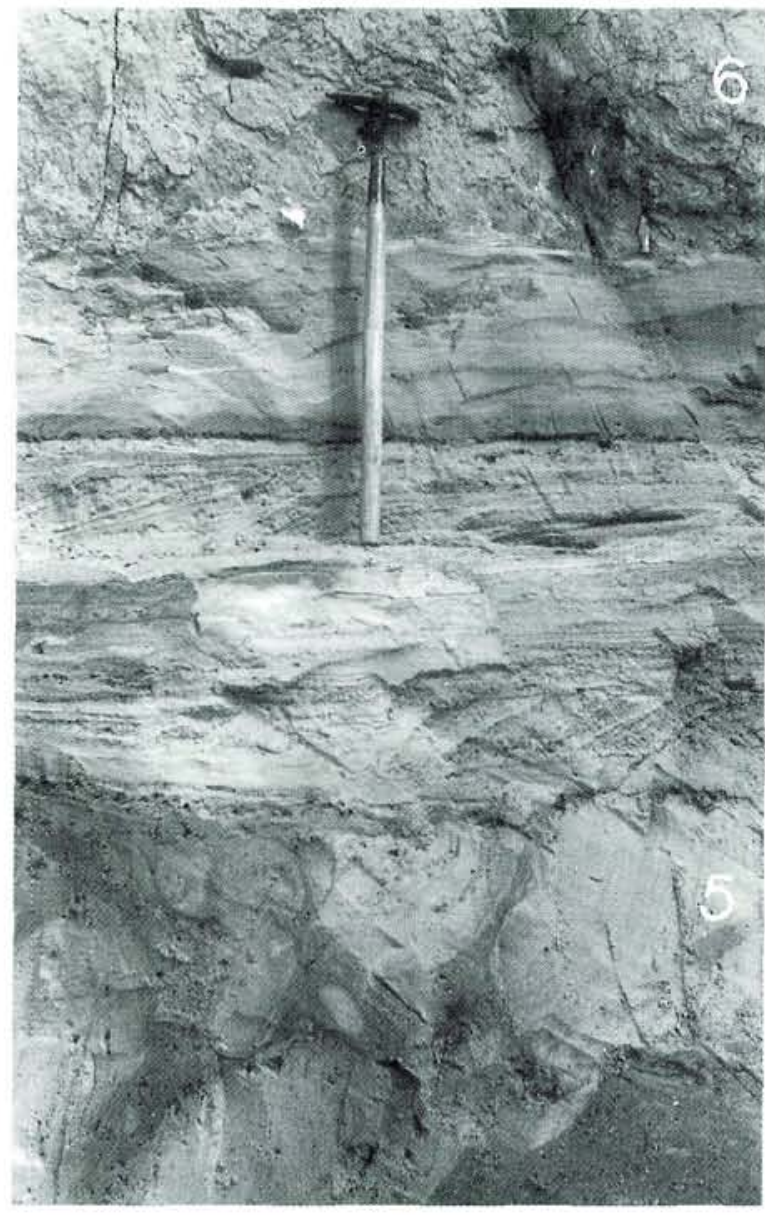

Fig. 9. Bedded gravel, sand and mud with involutions (unit 5) overlain by grey till (unit 6), site 7 . Handle is $0.5 \mathrm{~m}$.

\section{Lower lake sediments}

Unit 7 is composed of up to $5 \mathrm{~m}$ of crudely bedded, vivianite-bearing clay and mud containing strata-bound cracked mudballs and interveined with discontinuous $\mathrm{cm}$ thick lenses of fine sand and silt (sites 1-9, Figs 5, 11 \& 15). The transition from the underlying diamicton is gradual and the upper boundary is somewhat arbitrarily placed at the occurrence of meter thick beds of silty sand (Figs $10 \& 11$ ). The mud occasionally contains twigs and small amounts of plant detritus. Pollen analyses, modified from Kolstrup \& Houmark-Nielsen (1991) indicate high percentages of Calluna and other Ericales, moderate amounts of Betula and Filices and occasionally high percentages of Pinus (Fig. 15, 1).

Unit 7 represents a change from subaqueous supraglacial conditions to ice-free, lacustrine environments. The mud was deposited from suspension in a fresh water

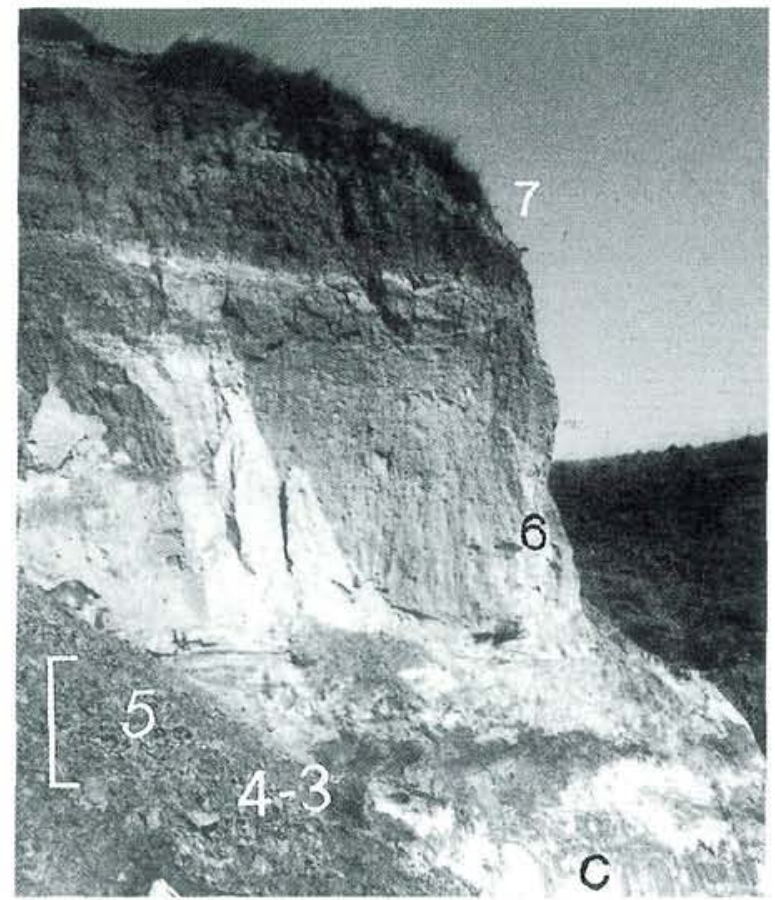

Fig. 10. Thick grey till (unit 6) overlying units 5, 4-3 and gradually overlain by bedded lacustrine mud (unit 7 ), site 7 . Scale is $2 \mathrm{~m}$. C. raft of Cretaceous chalk.

basin into which wind blown sand and silt occasionally settled. The presence of vivianite indicates decomposition of organic matter in an anoxic environment under free groundwater circulation (Rosenqvist 1970; Postma 1981). Cracking of the mud could be associated with periodically drought and strong frost action. The vegetation that surrounded the lake basin was almost treeless and was characterized by heather and dwarf shrubs with local stands of Pinus and Betula.

\section{Upper lake sediments}

Unit 8 comprises more than $10 \mathrm{~m}$ of bedded mud and fine sand with increasing amounts of clayey diamicton and occasional gravel beds towards the top (sites 1-8; Figs 5, $12 \& 15)$. The upper boundary is marked by a glaciotectonic unconformity and the lower gradually rests conformably upon unit 7 .

The sand and silt beds are well sorted (Kolstrup \& Houmark-Nielsen 1991), and sand grains are well to sub-rounded, some showing marks of intergranular collision. According to Kolstrup \& Houmark-Nielsen these beds resemble sand loess.

The mud of unit 8 is mostly massive but it may contain 


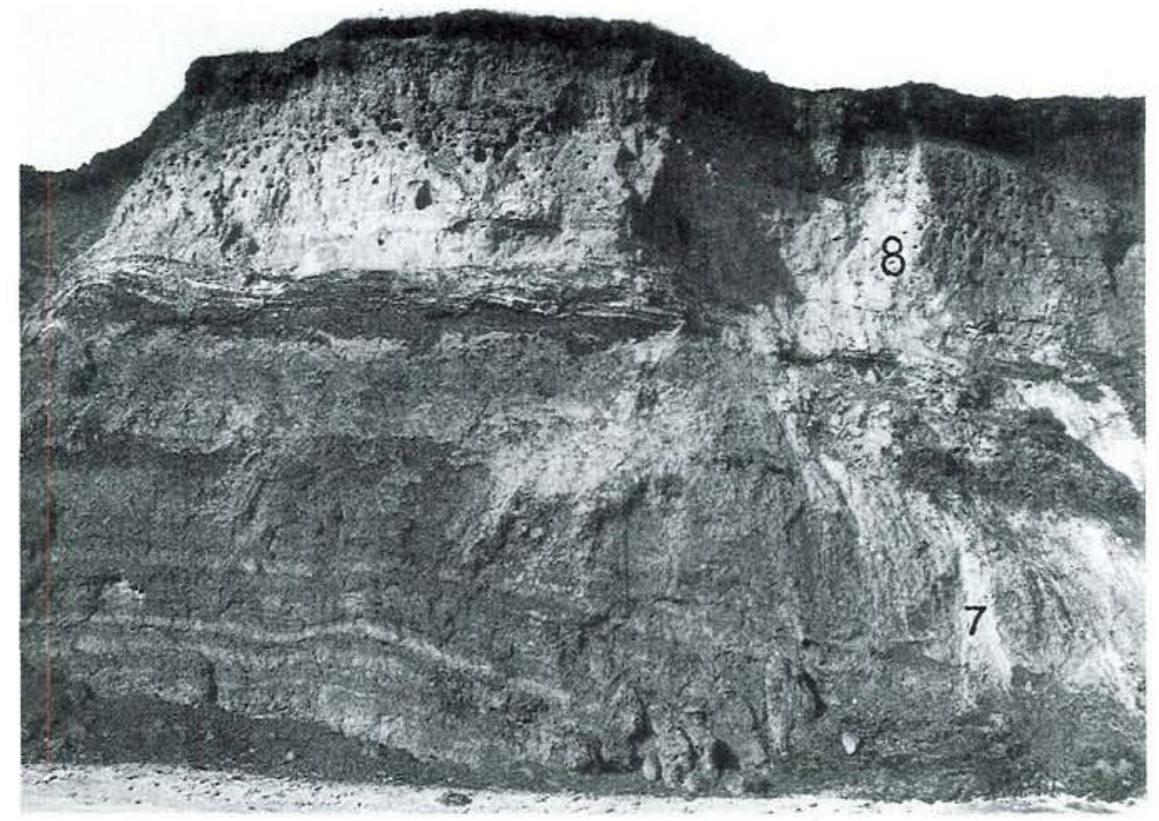

Fig. 11. Bedded lacustrine mud (unit 7) overlain by sand and silt (unit 8), site 2A. Cliff section is c. $10 \mathrm{~m}$ high.

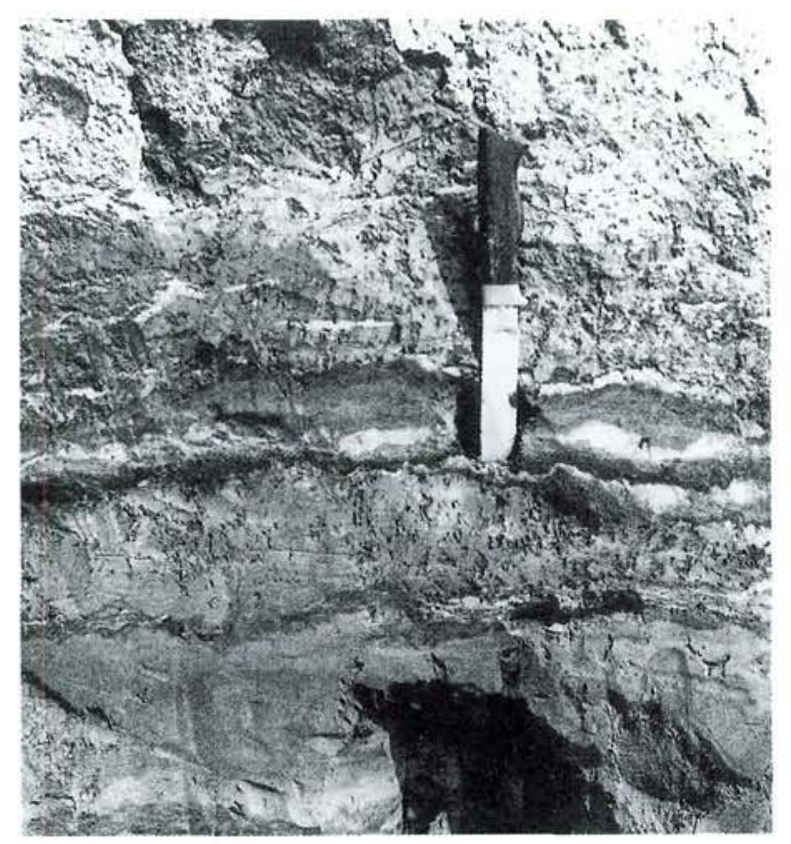

Fig. 12. Bedded sand and mud with organic detritus (lower part of unit 8 ), site $2 \mathrm{C}$. Knife is c. $20 \mathrm{~cm}$ in length.

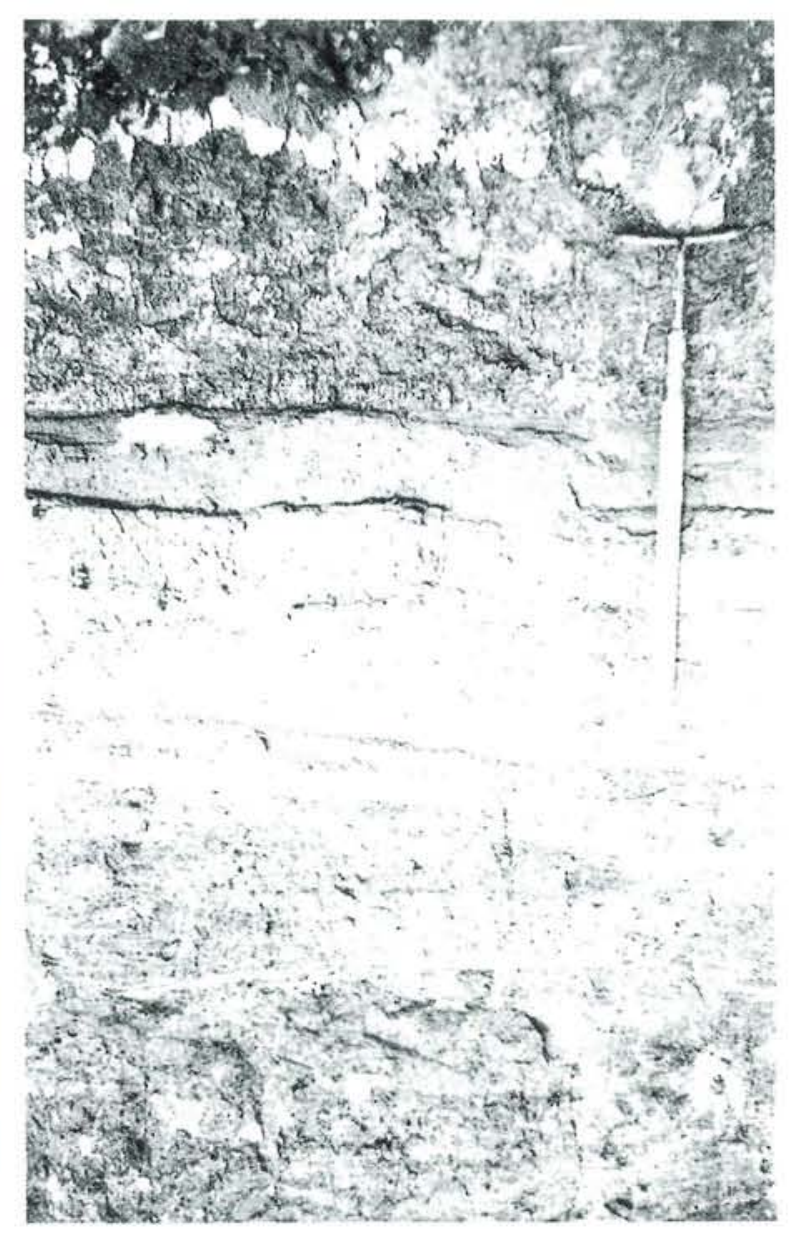

Fig. 13. Sand and silty clay interbedded with diamict mud (upper part of unit 8), site $4 \mathrm{C}$. Handle is $0.5 \mathrm{~m}$. 


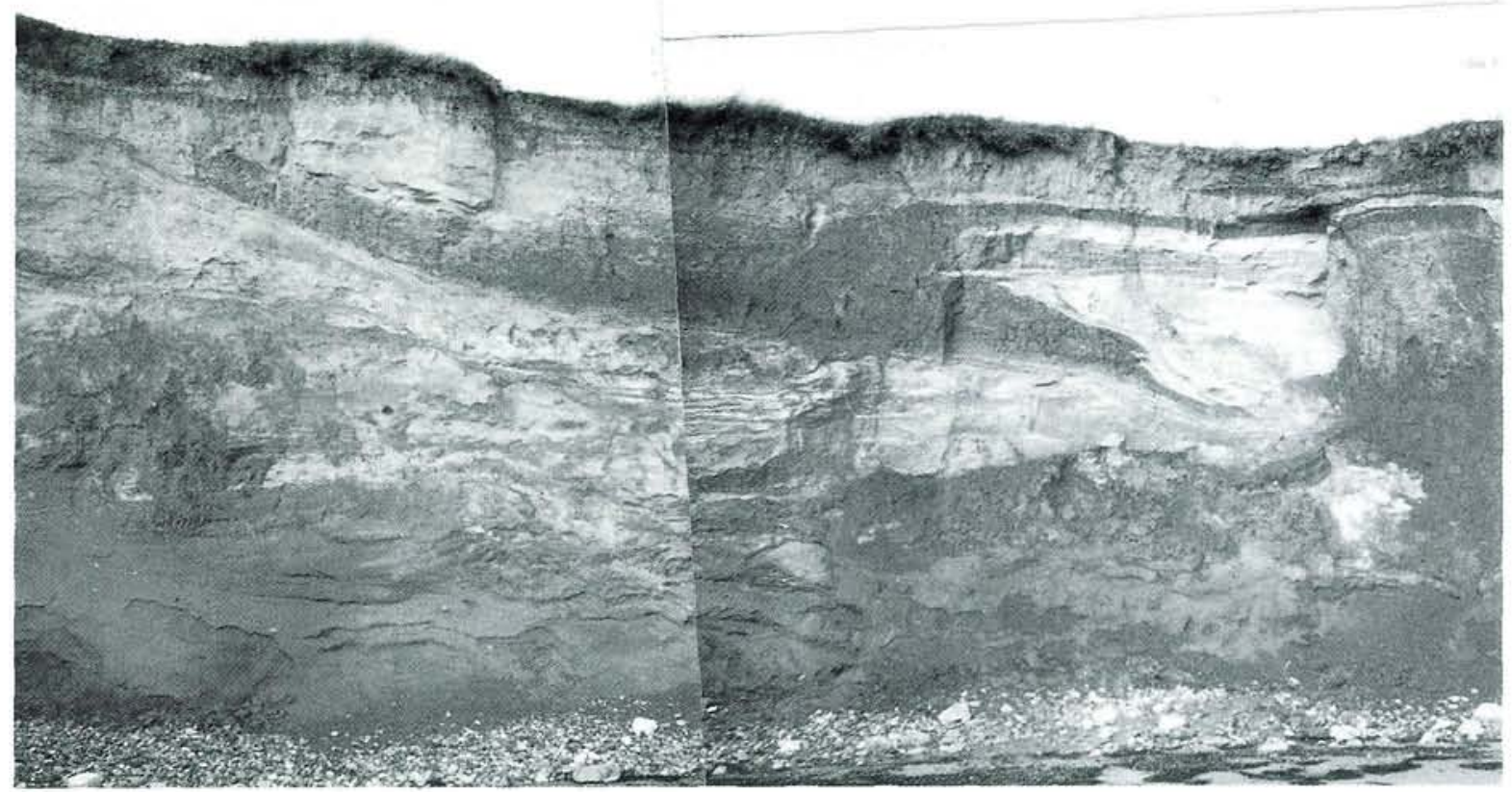

Fig. 14. Strongly glaciotectonically folded and thrusted sand and muddy diamicton (upper part of unit 8), site 4E. Cliff section is c. $10 \mathrm{~m}$ in height.

small discontinuous beds of fine sand with conspicuous amounts of plant remains (Fig. 12). Twigs of several $\mathrm{cm}$ in length appear among the dark brown plant detritus. Terrestrial macrofossils (Bennike et al. 1994) may include Carex, Salix, Betula nana, Dryas octopetala, Succinea oblonga, insects as well as the lemmings Lemmus lemmus and Dicrostonyx torquatus. Limnic macrofossils include Ranunculus, Daphnia pulex, Lymnaea peregra, Gyraulus laevis and Pisidium (Fig. 15).

Pollen analyses modified from Kolstrup \& HoumarkNielsen (1991), indicate high percentages of Cyperaceae, Poaceae and Artemisia (Fig. 15: 2, 3 and 4). Ericales, Filices and Betula are present in notable but upward decreasing numbers and Juniperus, Salix, Pinus and Thalictrum are present in very small quantities.

Interbedding the sand and fine grained facies of unit 8 , clayey and pebbly mud grading into muddy matrix-supported diamicton becomes increasingly more significant towards the upper parts (Fig. 13). Much of the diamict facies contains a characteristic fine gravel assemblage which does not resemble other diamictons around Klintholm. The clast composition indicates that local rock debris is almost absent and the total domination of Palaeozoic limestone and shale suggests sources in the Öland Gotland region of the Baltic (samples 33-39; Fig. 15). These deposits could hardly have originated from redeposition and solifluction of local sediments since no such compositions are found in the older units around Klintholm. It is proposed that the clast material could have been deposited from floating ice or icebergs the origin of which could be a calving glacier-front situated in the southern part of the Baltic, east of Møn.
Towards the very top of unit 8 diamict gravity flows and fluvial gravel beds contain an admixture of local and Baltic rock fragments suggesting erosion and remobilisation of glacigenic sediments already present in the area (samples 40-44; Fig. 15).

Unit 8 represents the infilling of a lake basin. Mud was deposited from suspension and diamicton probably settled as sediment gravity flows or ice-rafted debris. The fine sand and silt was probably blown into the basin and the organic detritus was washed out from the shore and hinterland. The vegetation was subarctic, treeless and herb dominated with scattered shrubs.

\section{Upper till}

Unit 9 is a $1-3 \mathrm{~m}$ thick reddish brown, mostly banded matrix-supported diamicton locally draping the cliff surface (Figs $5 \& 15$ ). It unconformably overlies glaciotectonically deformed older sediments. Folds and overthrusts indicate direction of glacier deformation from southeasterly directions (Figs $14 \&$ \& 15). The lower boundary is often blurred and it may not be possible to distinguish the till from strongly sheared subjacent sediments. Clast compositions indicate Baltic provenance with small amounts of local material (samples 45-47; Fig. 15). Unit 9 is interpreted as a till deposited from a glacier that was moving through the Baltic depression and was responsible for the strong glaciotectonic deformation of sediments beneath the till. 


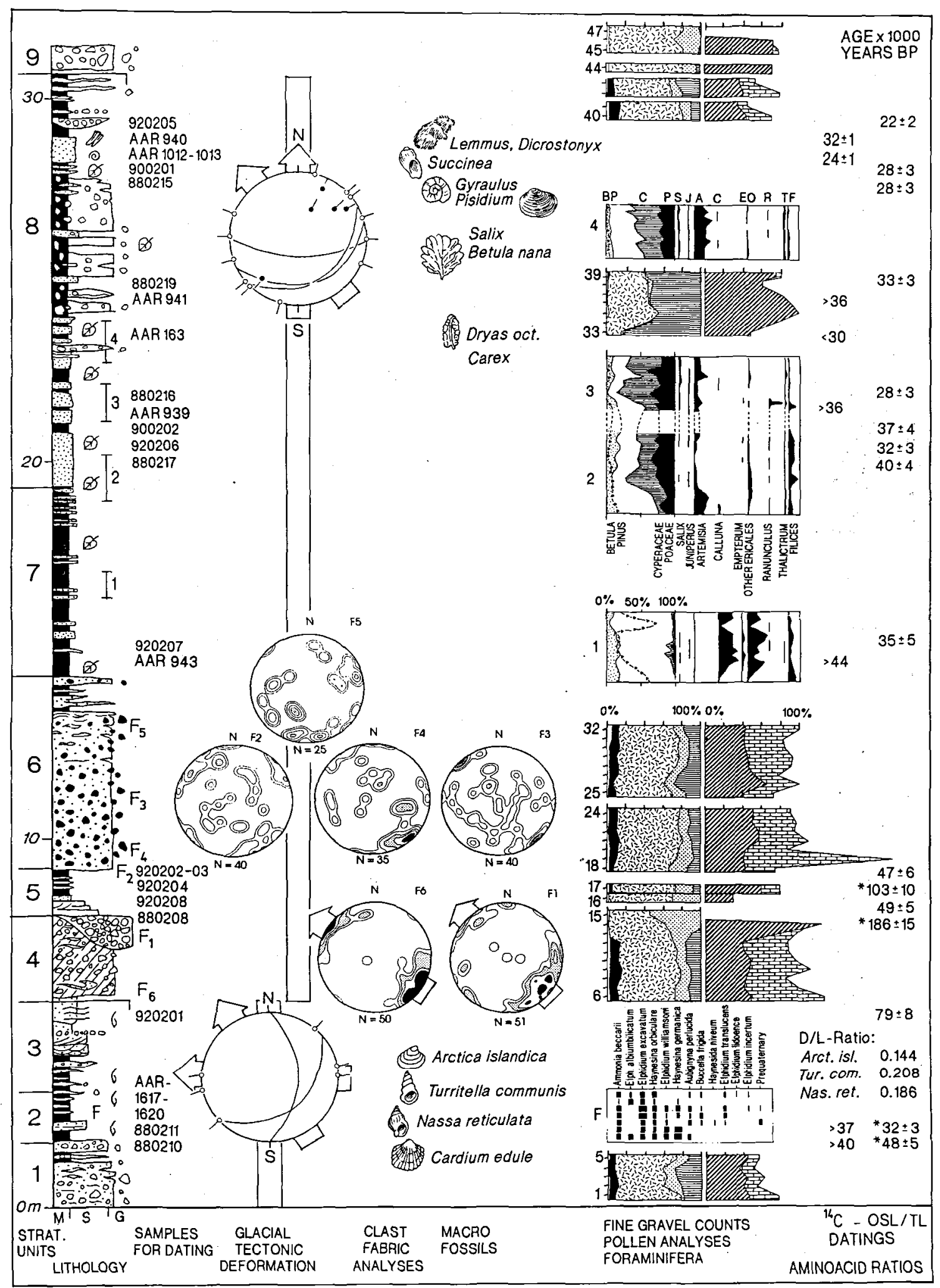




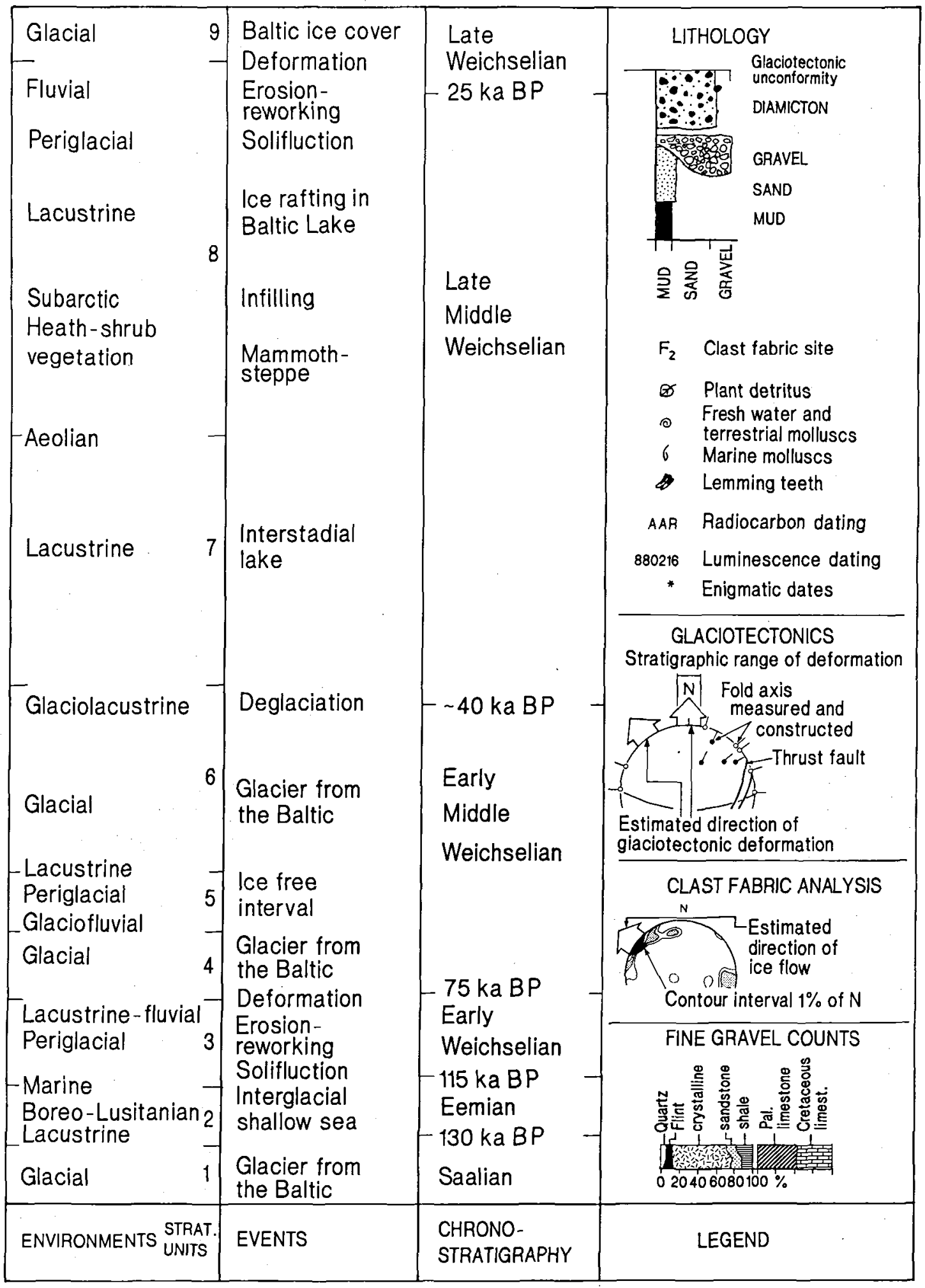

Fig. 15. Simple and composite lithostratigraphic logs, Kobbelgård and Kraneled. 


\section{Geochronology}

The total $\mathrm{D} / \mathrm{L}$ ratio (Alloisoleucine:isoleucine) was analyzed in shells of Arctica islandica, Turritella communis and Nassa reticulata from unit 2 (Table 1, Fig. 15). When compared with an index of international standards for amino acid stratigraphy (Miller \& Mangerud 1986), the values from Møn show close similarity to marine Eemian deposits elsewhere in southern Denmark and northern Germany. Moreover, values are considerably higher than the Early- to Middle Weichselian in northern Denmark (Skærumhede series) and much lower than values ascribed to the Holsteinian interglaciation from Denmark and Schleswig-Holstein. Thus, correlation with the Eemian can be demonstrated for the marine sediments by means of aminoacid chronology.

Table 1. Amino acid ratios of marine molluscs, unit 2, site 8, Kraneled.

\begin{tabular}{|c|c|c|c|}
\hline$R$ & SPECIES & HYDROLYSATE & $\begin{array}{c}\text { FREE } \\
\text { FRACTION }\end{array}$ \\
\hline
\end{tabular}

\begin{tabular}{llcl} 
Alloisoleucine : isoleucine (D/L ratio), MøN & \\
BAL & ARCTICA & 0.143 & 0.461 \\
2775 A & ISLANDICA & 0.147 & 0.481 \\
& & 0.151 & \\
BAL & ARTICA & 0.132 & 0.426 \\
2775 B & ISLANDICA & 0.149 & 0.435 \\
BAL & TURRITELLA & 0.227 & 0.340 \\
2776 A & COMMUNIS & 0.210 & 0.327 \\
& & 0.221 & 0.342 \\
BAL & TURRITELLA & 0.204 & 0.398 \\
2776 B & COMMUNIS & 0.190 & 0.383 \\
BAL & NASSA & 0.204 & 0.398 \\
2777 A & RETICULATA & 0.192 & 0.338 \\
BAL & NASSA & 0.174 & 0.328 \\
2777 B & RETICULATA & & \\
\hline
\end{tabular}

\section{Numerical dating}

A series of samples was taken for radiocarbon and luminescence dating (Fig. 5). In the few cases where both dating techniques have been applied to corresponding stratigraphic levels the results show that the ages can be matched with fairly good agreement. When finite ${ }^{14} \mathrm{C}$ ages of redeposited biogenic material are compared with absolute ages of sediments it must be noted that radiocarbon dates of the Late Weichselian (25-10 ka BP) may be underestimated by up to $3 \mathrm{ka}$ when compared with uranium-thorium ages (Bard, Arnold, Fairbanks \& Hamelin 1993). In connection with TL and OSL ages, Mejdahl et al. (1992) point out that it is uncertain to what extent the correction-factor adjusting sediment ages should be applied to Late Glacial deposits. V. Mejdahl (personal communication 1992) advises application of the correction factor for all ages obtained under the present investiga- tion. However, applying the correction factor to Middle Weichselian deposits may give a slight overestimation of the age, since the correction factor primarily has been tested out on Eemian and Early Weichselian deposits. Therefore, the difference between conventional radiocarbon ages and calendar years ideally indicated by luminescence dating may be insignificant when methodological uncertainties and geological factors are taken into account. In the present investigation, dates will be given as conventional radiocarbon years and uncorrected as well as corrected TL/OSL ages.

\section{Radiocarbon ages}

Radiocarbon dates on twigs of wood from units 7 and 8 (AAR 939, 941, 943) gave non-finite ages $(>36->44 \mathrm{ka}$ ) except for one (AAR 940) showing $32 \pm 1 \mathrm{ka} \mathrm{BP}$ in the upper parts of unit 8 (Table 2; Fig. 15 ). ${ }^{14} \mathrm{C}$ dates of gyttja (AAR 163, Kolstrup \& Houmark-Nielsen 1991) gave an age of $\leq \mathrm{c}$. $30 \mathrm{ka}$ BP for parts of the sequence analysed for pollen. The bones and teeth of lemmings (AAR 1012, AAR 1013) gave ages of $24.7 \pm 0.55 \mathrm{ka} \mathrm{BP}$ and $24 \pm 0.5$ ka BP.

Radiocarbon dates from unit 2 of molluse shells of Macoma baltica (AAR 1617, AAR 1619, Cardium edule (AAR 1618) as well as Nassa reticulata and Turritella communis (AAR 1620) gave non-finite ages mostly older than $40 \mathrm{ka}$.

As would be expected, the radiocarbon dated shells from the marine interglaical deposits show non-finite ages. ${ }^{14} \mathrm{C}$ dating also indicates that plant detritus older than 36-44 ka and material with ages of $32 \mathrm{ka}$ and less than $30 \mathrm{ka}$ was washed into the lake basin. The ages of lemmings show that sedimentation prevailed until at least 24 ka BP.

Table 2. Radiocarbon datings, Kobbelgård and Kraneled sections, Møn.

\begin{tabular}{lcccc}
\hline LAB. NR & SAMPLE & UNIT & $\delta^{13} \mathrm{C} \%$ & ${ }^{14} \mathrm{C} \mathrm{AGE}$ \\
AAR- & TYPE & NR & PDB & ka BP \\
\hline
\end{tabular}

\section{RADIOCARBON DATES MØN}

\begin{tabular}{llllc} 
AAR-163 & gyttja & 8 & -25 est & $<29.8$ \\
AAR-939 & wood & 8 & -24.8 & $>36$ \\
AAR-940 & wood & 8 & -24.8 & $32 \pm 1$ \\
AAR-941 & wood & 8 & -26.2 & $>36$ \\
AAR-942 & wood & 8 & -26.7 & no result \\
AAR-943 & wood & 7 & -25.1 & $>44$ \\
AAR-1012 & bone & 8 & -19.2 & $24.7 \pm .55$ \\
AAR-1013 & teeth & 8 & -20 est & $24 \pm .5$ \\
AAR-1617 & shell & 2 & -25 & $>40$ \\
AAR-1618 & shell & 2 & -25 & $>40$ \\
AAR-1619 & shell & 2 & -25 & $>40$ \\
AAR-1620 & shell & 2 & -25 & $>37$ \\
\hline
\end{tabular}




\section{Luminescence ages}

TL and OSL dates have been made on sediments from units 2, 3, 5, 7 and 8 (Fig. 15, Table 3). Because dated units are composed of grains with a multiple erosional and depositional history, the sediments listed in Table 3 often have double designation. The fine sands of units 7 and 8 are characterized as aeolian/lacustrine indicating that, even though much sand and silt was blown into the area, sedimentation in the lake may have been accompanied by reworking and mixing with deposits washed into the basin by rivers from the uplands. In other cases bedded sand and mud may represent both fluvial and lacustrine environments.

The nine luminescence datings of sand and silt from units 7 and 8 indicate deposition in the lake basin from about 40 to $22 \mathrm{ka} \mathrm{BP}$ (Fig. 15). There is a clear trend of ages being younger towards the top of the sequence as well as a reliable match with radiocarbon ages from the top of unit 8 .

Three dates from unit 5 show ages around $47-49 \mathrm{ka} \mathrm{BP}$ while two dates suggest ages at 103 and $186 \mathrm{ka} \mathrm{BP}$ (Fig. 15). Obviously the pre-Eemian (186 ka BP) age is much too old and the $103 \mathrm{ka}$ dating may signal zeroing during the Early Weichselian. Consequently the age of unit 5 most probably lies around $50 \mathrm{ka} \mathrm{BP}$.

One age of $79 \mathrm{ka} \mathrm{BP}$ was obtained from redeposited marine sand (unit 3; Fig. 15). This suggests that rework- ing of Eemian and older sediments occurred during the close of the Early Weichselian, just prior to the ice advance that deposited the till of unit 4 .

Two luminescence datings were made on the marine Eemian sediments (Fig. 15). The obtained ages of 32 and $48 \mathrm{ka} \mathrm{BP}$ seem to be about $80 \mathrm{ka}$ too young compared to the accepted age for the Eemian (cf. Mangerud 1989). Such a large underestimate can not be justified by the effect reported by Mejdahl et al. (1992); technically the dates are reported to have good plateaus, the material was well bleached and the ages suggest a zeroing event much younger than the Eemian. The causes of this event are ambiguous. The sequence containing the marine deposits is moderately tilted due to glaciotectonic stacking and thrusting but individual thrust slices apparently show little or no sign of internal displacement or shearing (site 8, Fig. 4). If glaciotectonic processes are capable of zeroing a luminescence signal or resedimentation has taken place, this would have happened before deposition of the grey-red till (unit 4) which unconformably overlies the tilted sequence. Glacier loading occured several times during the Weichelian. This effect has been debated by Aitken (1985), however, its possible impact on the luminescence datings from Møn is uncertain.

The luminescence ages of the marine sediments from Klintholm seem enigmatic but not unique. Thus TL-dates of the Cyprina clay of Rügen (Steinich 1992) gave an age of $27 \pm 3 \mathrm{ka} \mathrm{BP}$ (uncorrected). New dates from Møn are

Table 3. Luminescence datings, Kobbelgård and Kraneled sections, Møn and Ristinge Klint. TL: Thermoluminescence, OSL: Optically stimulated luminescence. Correct. Ages are corrected after the recomendations of Mejdahl et al. (1992). Aeol: Aeolian, Lac: \& lacu: Lacustrine, Fluv: Fluvial, Sa: Sand, Si: Silt, Cl: Clay.

\begin{tabular}{lcccccc}
\hline UNIT/ & SEDIMENT TYPE & RIS & TL & OSL & TL+OSL & CORRECT. \\
SECTION & & LAB NR R- & $(\mathrm{ka})$ & $(\mathrm{ka})$ & \begin{tabular}{c} 
TL - OSL \\
\hline
\end{tabular}
\end{tabular}

\section{LUMINESCENCE DATES MØN}

$\begin{array}{ll}5 / 7 & \text { Fluvial sand } \\ 2 / 8 & \text { Marine sand } \\ 2 / 8 & \text { Marine clay } \\ 8 / 6 & \text { Aeol/lac sa-si } \\ 8 / 8 & \text { Aeol/lac sa-si } \\ 8 / 2 & \text { Aeol/lac sa-si } \\ 8 / 2 & \text { Aeol/lac sa-si } \\ 8 / 2 & \text { Aeol/lac sa-si } \\ 8 / 2 & \text { Aeol/lac sa-si } \\ 3 / 10 & \text { Fluv/marine sa } \\ 5 / 9 & \text { Lacu/flu sa-ci } \\ 5 / 10 & \text { Lacu/flu sa-si } \\ 5 / 7 & \text { Lacu/fluv sa } \\ 8 / 4 & \text { Aeol/lac sa-si } \\ 8 / 3 & \text { Aeol/lac sa-si } \\ 7 / 1 & \text { Aeol/lac sa-si } \\ 5 / 9 & \text { Fluv/lac sand }\end{array}$

\section{LUMINESCENCE DATES RISTINGE KLINT}

$\begin{array}{ll}\text { Eem } & \text { Limnic sa/cl } \\ \text { Yellow. sand } & \text { Fluvial } \\ & \text { sand } \\ \text { White sand } & \text { Aeol-fluv } \\ & \text { sand }\end{array}$

$\begin{array}{lcccc}880208 & 137 \pm 12 & & 137 \pm 12 & 186 \pm 15 \\ 880210 & 22 \pm 2 & 23 \pm 2 & 23 \pm 2 & 32 \pm 3 \\ 880211 & 36 \pm 4 & 34 \pm 3 & 35 \pm 4 & 48 \pm 5 \\ 880215 & 20 \pm 2 & & 20 \pm 2 & 28 \pm 3 \\ 880216 & 20 \pm 2 & & 20 \pm 2 & 28 \pm 3 \\ 880217 & & 29 \pm 4 & 29 \pm 4 & 40 \pm 4 \\ 880219 & 24 \pm 3 & & 24 \pm 3 & 33 \pm 3 \\ 900201 & 20 \pm 2 & & 20 \pm 2 & 28 \pm 3 \\ 900202 & 27 \pm 3 & & 27 \pm 3 & 37 \pm 4 \\ 920201 & 58 \pm 6 & 58 \pm 6 & 58 \pm 6 & 79 \pm 8 \\ 920202 & 34 \pm 3 & & 34 \pm 3 & 47 \pm 5 \\ 920203 & 33 \pm 3 & 34 \pm 3 & 34 \pm 3 & 47 \pm 5 \\ 920204 & 79 \pm 8 & 73 \pm 7 & 76 \pm 7 & 103 \pm 10 \\ 920205 & 16 \pm 2 & 16 \pm 2 & 16 \pm 2 & 22 \pm 2 \\ 920206 & 23 \pm 2 & & 23 \pm 2 & 32 \pm 3 \\ 920207 & & 25 \pm 3 & 25 \pm 3 & 35 \pm 3 \\ 920208 & 36 \pm 5 & & 36 \pm 5 & 49 \pm 5\end{array}$

$\begin{array}{llll}880202 & 85 \pm 8 & 85 \pm 8 & 115 \pm 12 \\ 880203 & 18 \pm 3 & 18 \pm 2 & 25 \pm 3 \\ 880204 & 20 \pm 2 & 20 \pm 2 & 28 \pm 3 \\ 880205 & 72 \pm 7 & 72 \pm 7 & 98 \pm 10 \\ 880206 & 43 \pm 5 & 43 \pm 5 & 59 \pm 6\end{array}$


needed to throw light on the discrepancy between resemblence with the Eemian interglacial as signaled by both microfossil contents and amino acid ratios and the late Middle Weichselian luminescence ages. However, it should be mentioned that TL dates of lower Eemian freshwater deposits from Ristinge gave an age of $115 \pm 12$ ka BP (Table 3) indicating that not all datings of Eemian deposits are severely underestimated.

As a whole, the luminescence dates from the Klintholm sections indicate ages of three depositional episodes that can be dated with some confidence. The oldest and least well founded suggests reworking of marine sediments at the end of the Early Weichselian. The second episode reflects an early Mid Weichselian interlude with fluvial and lacustrine deposition between the two older Weichselian ice advances; it occurred slightly after $50 \mathrm{ka} \mathrm{BP}$. The third and best documented episode represents the infilling of a lake basin that took place during the later part of the Middle Weichselian, roughly between 40 and $20 \mathrm{ka} \mathrm{BP}$.

\section{Discussion and correlation}

Preliminary evidence from Møn was incorporated along with other available stratigraphic and palaeontological data into a palaeogeographic model of the Late Pleistocene evolution of Southwest Scandinavia (HoumarkNielsen 1989). The results of the present investigation have not suggested any modification of the fundamental aspects of this outline.

The cliff sites around Klintholm expose a composite stratigraphy and deformational chronology reflecting environmental changes through several stages of the Late Pleistocene (Fig. 15). It can be demonstrated that the last interglaciation on Møn was characterized by shallow water, brackish to marine boreo-lusitanian environments. The marine facies (unit 2) closely resemble that of the so-called Cyprina clay described by Madsen, Nordmann \& Hartz (1908) and deposited during the Eemian interglaciation (Nordmann 1928). Recent analyses made by Konradi (1976), Knudsen (1985, 1991), Penny (1989) and Kristensen (1993) fully comfirm Nordmann's stratigraphic interpretation. Kristensen (1993) suggested that the uppermost part of the marine deposits at Klintholm could belong to the Early Weichselian due to its contents of a cold faunal element. A correlation with the boreal to arctic Cyprina clay of Rügen could be tempting due to similarity in luminescence ages. However, the late Middle Weichselian age proposed by Steinich (1992) and Frenzel (1993) is incompatible with the palaeoenvironmental conclusions and amino acid correlations from the present investigation, even though Frenzel indicates some similarity in foraminiferal faunas.

Interglacial conditions on Møn were succeeded by periglacial environments causing fluvial erosion and gravitational reworking of Eemian and older sediments (unit 3 ) and this apparently took place until about $80 \mathrm{ka} \mathrm{BP}$. At
Brørup, periglacial environments that characterize the Early Weichselian were interrupted by interstadial conditions and were reported by Andersen (1961). The environments that characterize the Brørup interstade have not been registered at Klintholm, although Kolstrup \& Houmark-Nielsen (1991) suggested the presence of possibly redeposited pollen of Early Weichselian age in unit 7. Hamberg (1989) demonstrated that the so called "white sand" sandwiched between the Cyprina clay and the Ristinge Klint Till (Houmark-Nielsen 1987) was deposited on a flood plain with aeolian sand sheets under periglacial conditions. Even though uncertainties exist as to the exact location of dated samples, luminescence ages of the white sand indicates deposition some time between 98-59 ka BP suggesting an Early Weichselian age that antedates the first Weichselian ice advance (Table 3). A similar stratigraphic position could be held by the fluvial sand overlying the limnic Eemian beds at Hollerup (Andersen 1961) which were TL dated by Kronborg \& Mejdahl (1989) and Petersen \& Kronborg (1991) to about 65-75 ka BP corresponding to ages between 88 and 102 ka BP when corrected for the effect of shallow traps (Mejdahl at al. 1992).

In the Klintholm sections, subsequent early Middle Weichselian glacial environments are indicated by glaciotectonic deformation and till deposition (unit 4) from an ice stream moving through the Baltic. Luminescence datings from Møn apparently frame this ice advance to have occurred roughly between 80 and $50 \mathrm{ka} \mathrm{BP}$. It is tentatively suggested that the grey-red till (unit 4) can be correlated with the Ristinge Klint Till. This till is a Baltic and reddish to grey diamicton sandwiched between the white and the yellow sand (Houmark-Nielsen 1987) and, according to Table 3, deposited after the Early Weichselian and before the Late Weichselian. The idea that red tills are restricted to pre-Weichselian glaciations (Ehlers 1992) due to the sizes of consecutive Scandinavian ice sheets (the Weichselian being the smallest) can thus no longer be maintained.

At Klintholm an ice-free interval most likely occurred around $50 \mathrm{ka} \mathrm{BP}$ around Klintholm causing deposition of a fining upward sequence (unit 5). It signals a change from glacio-fluvial to (glacio?) lacustrine environments. Involutions in the lower part of the sequence suggest subaerial periglacial conditions during periods of nondeposition. Possibly some of the redeposited pollen and spores along with plant fragments with non-finite radiocarbon ages from units 7 and 8 could originate from this non-glaciated interval. Thus Kolstrup (1992) and Kolstrup \& Havemann (1984) have reported on periglacial vegetation types with radiocarbon ages around or slightly older than $50 \mathrm{ka}$ BP from the western part of Denmark.

A subsequent ice advance led to deposition of the thick grey till (unit 6). Renewed ice growth and climatic changes could have caused glaciers to surge westwards through the Baltic depression. Eventually, environments changed from glacial to glaciolacustrine during deglaciation.

It seems probable that the Møn area experienced two 
glacial phases during the Middle Weichselian. The older probably corresponds to a glaciation that covered most of southeast Denmark east of Brørup (cf. Petersen 1984, Houmark-Nielsen 1989). It is tempting to suggest that some of the North German red tills ascribed to the end of the Saalian could in fact be of Weichselian age.

The younger ice advance could be equivalent to the glacier which deposited Baltic till underlying Middle Weichselian marine deposits at Holmstrup (Petersen \& Buch 1974) provided its post-Eemian age can be demonstrated. Other traces of Baltic tills older than the Late Weichselian maximum from northern Sjælland (Houmark-Nielsen 1987; Nielsen 1987) could be associated with this ice. This could also be the case with the older Baltic till on Sejerø (Houmark-Nielsen \& Kolstrup 1981, Houmark-Nielsen 1987) on condition that the radiocarbon ages of the subjacent limnic deposits containing remains of a treeless vegetation are too young. In order to test the radiocarbon ages re-dating of sediment from these strata by the luminescence method are beeing preformed, thus the published TL-dates of c. $36 \pm 4$ ka BP (Kronborg 1984) could be underestimated by as much as $13 \mathrm{ka}$ when corrected after the recommendations of Mejdahl et al. (1992).

Whether or not these older Weichselian ice streams reached the northern Kattegat region is still an open question. The provenance of ice-rafted debris of postulated Baltic origin from Vendsyssel (Petersen 1984) can readily be demonstrated as Fennoscandian and local when published gravel counts from the Skxrumhede II boring are taken into account (Bahnson, Petersen, Konradi \& Knudsen 1974). Kronborg \& Mejdahl (1989), Kronborg et al. (1990) and Petersen \& Kronborg (1991) have suggested that the western and northern parts of Denmark also were glaciated during the Early or Middle Weichselian. This theory must, however, be regarded as highly speculative until more persuasive stratigraphic evidence is published.

During the late Middle Weichselian (40-25 ka BP), a climatic change led to retreat of the Fennoscandian ice sheet in the Baltic region. At Klintholm, periglacial and lacustrine conditions around 40-30 ka BP led to deposition of muddy sediments (unit 7) in a lake basin in the western Baltic. Speculations on the size and distribution of the lake just as its connection to the possible outlet through the Alnarp valley (Lagerlund 1987) is avoided at present. However, the deposition of muddy diamicton totally dominated by a clast composition from the southcentral parts of the Baltic suggests ice rafting in a larger and regionally confined basin. Biota were dominated by subarctic heath and dwarf shrubs similar to the mammoth steppe (Berglund \& Lagerlund 1981; Aaris-Sørensen et al. 1990). The gradual infilling of the lake basin during deposition of unit 8 with increasing amounts of muddy diamictons and aeolian sediment took place until about $22 \mathrm{ka} \mathrm{BP}$. A possible climatic deterioration caused increased solifluction, and the vegetation became almost totally dominated by grasses and sedges. The environ- mental conditions are further discussed by Bennike et al. (1994).

In the circum-Baltic region and Southwest Scandinavia, correlation based on pollen records of sites that are radiocarbon dated to the late Middle Weichselian (40-25 ka BP) is problematic due to admixture of older pollen and spore types (Kolstrup \& Houmark-Nielsen 1991; Bennike et al. in press). However, as stated by Kolstrup (1992), different types of vegetation may have co-existed in northern Europe during most of the Weichselian giving rise to incompatible pollen records. Published evidence conclude that, prior to the Late Weichselian glaciation maximum, subarctic vegetation types characterized by herbs, dwarf shrubs and sedges with or without scattered stands of trees characterize a number of key sites in the circum Baltic region. These may include localities in Sweden: Gärdslöv (Miller 1977), Dösebacka (Hillefors 1974, 1986), Denmark: Møn (Kolstrup \& Houmark-Nielsen (1991), Sejerø (Houmark-Nielsen \& Kolstrup 1981), Hirtshals (Odgaard 1982), Lithuania: Birzai (Gaigalas, Serebryanny \& Valueva 1992), Poland: Konin-Maliniec (Stanskowska \& Stankowski 1988) and Germany: Rügen (Steinich 1992).

The bedded diamictons with a characteristic clast composition almost free of local rock types could have been deposited by ice rafting due to renewed glacier growth in the Baltic. Weichselian pebbly diamict mud with a similar clast composition is overlain by the younger tills of the Late Weichselian maximum at Møns Klint and Hjelm Bugt (Hintze 1937; Sjørring personal communication 1993). The diamict mud was named: "the stone-free clay" by Hintze and it was possibly deposited in a glaciolacustrine setting (Hansen 1965). The diamicton and pebbly mud of eastern Møn (unit 8) is correlated with the oldest diamicton of similar clast composition overlying the Gärdslöv beds in Skåne (Nilsson 1973). This diamicton, the Allarp Till (Berglund \& Lagerlund 1981), was deposited in connection with the first Late Weichselian ice advance in southern Sweden. Petrographic studies (Böse 1990) indicate that the first Late Weichselian ice advance which overrode northern Germany and reached the Brandenburg stage has a composition comparable to the Allarp till and the bedded diamictons from Klintholm.

Consequently, the western part of the circum Balticregion possibly experienced glacier growth at the very end of the Middle Weichselian and, as a result, drifting ice was launched into a larger, partly glacier-confined basin. Finally, at least Skåne and eastern Germany were overridden by Baltic glaciers at the end of the Middle Weichselian.

After c. 22 ka BP during the Jylland stade (HoumarkNielsen 1989), Late Weichselian glaciers of the Main Weichselain advance overrode Southeast Denmark from the northeast and later the Young Baltic ice invaded from southeasterly directions. Traces of the Northeast-ice are apparently absent in the Klintholm sections, although large scale glaciotectonic structures and till deposits from this advance are found in Hjelm Bugt and Møns Klint 
(Aber 1979; Berthelsen 1981, 1986). At Klintholm, the younger phase of glaciotectonic deformation from the southeast and south and deposition of the discordant till (unit 9) were most probably associated with recessional phases of the Young Baltic glaciation. In several cliff sections, well preserved Late Glacial (c. 14-10 ka BP) lacustrine sequences are present (Kolstrup 1982, Heiberg 1991).

\section{Conclusions}

The combined stratigraphic sequence and environmental history from Klintholm (Fig. 15) reflects alternations of glaciated and non-glaciated periglacial conditions during the Late Pleistocene. The course of the geological evolution seems closely related to climatic changes. Moreover, glaciation events and sedimentation was largely controlled by the presence of the Baltic depression which acted as a marine and lacustrine sedimentary basin as well as a gateway for ice streams from the eastern part of Fennoscandia. The results of the present investigation allow the following conclusions:

1. On Møn marine deposits of the Eemian interglaciation is characterized by a shallow water boreo-lusitanian foraminifera fauna; amino acid ratios of mollusc shells resemble those of other Eemian sites in the region. Luminescence ages are at present enigmatic. In the Early Weichselian solifluction and redeposition of sediments in a periglacial environment took place until about $80 \mathrm{ka} \mathrm{BP}$.

2. During the earlier part of the Middle Weichselian (75-40 ka BP), glaciers moving through the Baltic depression invaded the region twice interrupted by an ice free interval around $50 \mathrm{ka}$ BP. The older ice advance may correspond to a pre-Late Weichselian Baltic glaciation recorded elsewhere in eastern Denmark. The younger may have been confined to the southeastern parts of the country.

3. Around Klintholm a lacustrine basin existed throughout the late Middle Weichselian (40-25 ka BP). Traces of the surrounding terrestrial biotas indicate a treeless heath and shrub vegetation of the mammoth steppe type. Subsequent infilling with diamict mud practically without local clast debris and dominated by Palaeozoic shale and limestone, suggests ice rafting from advancing glaciers into a regionally confined basin in the western part of the Baltic depression by the end of the Middle Weichselian (30-25 ka BP). During the Late Weichselian glacial maximum (20-15 ka BP) the overriding of ice streams eventually lead to strong glaciotectonic displacement of Late Pleistocene and pre-Quaternary deposits and to deposition of till.

\section{Dansk sammendrag}

I de senere år har danske kvartærgeologer ivrigt diskuteret alderen og udbredelsen af den første nedisningsfase i Weichsel. På Møn har nye glacialstratigrafiske studier, kombineret med unders $\varnothing$ gelser af flora og fauna og et omfattende dateringsprogram, afsl øret en kompleks lagfølge (Fig. $5 \& 15$ ) bestående af ni lithostratigrafiske enheder (enhed 1-9). En ældre till (1) er overlejret af marine aflejringer fra Eem-mellemistiden (2). Det marine ler er overlejret af flydejord (3) og to ældre Weichsel tills (4 og 6), der er adskilt af smeltevandsdannelser med involutioner (5). Den ældre till (5) har en karakteristisk

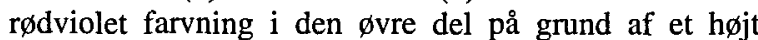
indhold af udvalsede røde sandsten fra den østlige del af $\emptyset$ stersøen. Den yngre till (6) er dækket af interstadiale søsedimenter, flyvesand og flydejord samt eventuelt isbjergs droppet materiale ( 7 og 8). Lagfølgen findes idag i stærkt istektonisk deformeret tilstand i klinterne omkring Klintholm på Sydøstmøn (Fig. 2 \& 4) og dækkes af et sporadisk till-dække (9). Undersøgelserne viser, at Baltiske isstrømme nåede frem til $\$ \emptyset$-Danmark tidligt i den mellemste del af sidste istid mellem 75 og $40 \mathrm{ka}$ BP. Afsmeltningen efterlod et større (Østersø?) -bassin, der i perioden $40-20 \mathrm{ka}$ BP opfyldtes af mudrede og sandede søsedimenter. Heri er fundet rester fra den sparsomme, steppelignende og træløse, arktiske vegetation, der omgav søbassinet. Dyrelivet er bl.a. repræsenteret ved de første sikre fund af lemming i Danmark. I Sen Weichsel overskred en Ung-Baltisk isstrøm området med og forårsagede stærke istektoniske forstyrrelser af lagfølgen omkring Klintholm.

\section{Acknowledgements}

Gratitude is expressed to the Carlsberg Foundation for supporting the field work and for financing the determination amino acid values and radiocarbon and luminescence datings. The majority of fine gravel counts were made by the late Steen Sjørring (Geological Institute, University of Copenhagen). Else Kolstrup (Geological Consulting Company, Sønderborg) were helpful in condensing previously published pollen data, and identifications of non-marine molluses were preliminarily made by Kaj Strand Petersen (Geological Survey of Denmark). Analyses of terrestrial and freshwater macrofossils were made by Ole Bennike (Geological Museum, University of Copenhagen), Erik Otto Heiberg (Geological Institute, University of Copenhagen) and Jens Böcker (Zoological Museum, University of Copenhagen). Studies of marine microfossils, especially foraminifera, were preliminarly made by Peter Konradi (Geological Survey of Denmark) and detailed examinations of closely spaced samples were undertaken by Peter Kristensen (Geological Institute, University of Aarhus).

Alloisoleucine:isolleucine (D/L) epimerization in marine mollusc shells were measured at the Bergen amino 
acid Laboratory (University of Bergen). Dates of sediments were made at the Nordic Laboratory for Luminescense Dating at Ris $\varnothing$ (University of Aarhus). Radiocarbon dates of organic material were made using the tandem accelerator method at the Institute of Physics and Astronomy (University of Aarhus). Vagn Mejdahl and Barbara Maut (Nordic Laboratory for Luminescence Dating at Ris $\varnothing$, University of Aarhus) were helpful in discussing the TL and OSL dating results. Svend Funder (Geological Museum, University of Copenhagen) made critical comments to the manuscript. John Bailey (Geological Institute, University of Copenhagen) kindly corrected the English language and René Madsen (Geological Institute, University of Copenhagen) gave the drawings their finish.

\section{References}

Aaris-Sørensen, K., Petersen, K. S. \& Tauber, H. 1990: Danish finds of mammoth (Mammuthus primigenius Blumenbach). Stratigraphical position, dating and evidence of Late Pleistocene environment.Damnarks Geologiske Unders $\emptyset$ gelse B 14, $44 \mathrm{pp}$.

Aber, J. 1979: Kineto-stratigraphy at Hvideklint, Møn, Denmark and its regional significance. Bulletin of the Geological Society of Denmark 28, 81-93.

Aber, J. 1985: The charcter of glaciotectonism. Geologie en Mijnbouw 64, 389-395.

Aitken, M. 1985: Thermoluminescence dating. Academic Press, New York, $351 \mathrm{pp}$.

Andersen, S. Th. 1961: Vegetation and its Environment in Denmark in the Early Weichselian Glacial (Last Glacial). Danmarks Geologiske Undersøgelse, II rk 61, $175 \mathrm{pp}$.

Bahnson, H., Petersen, K. S., Konradi, P. B. \& Knudsen, K. L. 1974: Stratigraphy of Quaternary deposits in the Skærumhede II boring: lithology, molluscs and foraminifera. Danmarks Geologiske Undersøgelse, Årbog 1973, 27-62.

Bard, E. Arnold, M., Fairbanks, R. G. \& Hamelin, B. 1993: ${ }^{230} \mathrm{Th}-{ }^{234} \mathrm{U}$ and ${ }^{14} \mathrm{C}$ ages obtained by mass spectrometry on corals. Radiocarbon 35(1), 191-199.

Behre, K-E. \& Lade, U. 1986: Eine Folge von Eem und 4 Weichsel-Interstadialen in Oerel / Niedersachsen und ihr Vegetationsablauf. Eiszietalter und Gegenwart 36, 11-36.

Bennike, O., Heiberg, E. O. \& Houmark-Nielsen 1993: Første danske lemminger. Naturens Verden 2, 57-63.

Bennike, O., Houmark-Nielsen, M., Böcher, J. \& Heiberg, E. O. 1994: A multi-diciplinary macrofossil study of Middle Weichselian sediments at Kobbelgård, Møn, Denmark. Palaeogeography, Palaeoclimatology, Palaeoecology 111.

Berglund, B. E., Håkansson, S. \& Lagerlund, E. 1976: Radiocarbon-dated mammoth (Mammuthus primigenius Blumenbach) finds in South Sweden. Boreas 5, 177-191.

Berglund, B. E. \& Lagerlund, E. 1981: Eemian and Weichselian stratigraphy in South Sweden. Boreas 10, 323-362.

Berthelsen, A. 1979: Contrasting views on the Weichselian glaciation and deglaciation of Denmark. Boreas 8, 125-132.

Berthelsen, A. 1981: Guide to INQUA-IGCP: Field meeting in Denmark, Glacial Tectonics. Institut for Almen Geologi, Københavns Universitet, $5 \mathrm{pp}$.

Berthelsen, A. 1986: Glaciotectonic structures in the cliffs of southern and eastern Møn, Denmark. Abstract INQUA's working group on glacial tectonics, Field meeting, Oct. 1986. Institut for Almen Geologi, Københavns Universitet, $3 \mathrm{pp}$.

Berthelsen, A., Konradi, P. B. \& Petersen, K. S. 1977: Kvartare lagfølger og strukturer i Vestmøns klinter. Dansk Geologisk Forening, Arsskrift for 1976, 93-99.
Böse, M. 1990: Reconstruction of ice flow directions south of the Baltic Sea during the Saalian and Weichselian glaciations. Boreas 19, 217-226.

Dansk Geologisk Forening 1990: Årets møder 1988. Dansk Geologisk Forening, Årsskrift for 1987-1989, 121.

Dreimanis, A., Hütt, G., Raukas, A. \& Whippey, P. W. 1985: Thermoluminescence Dating. In Nat. W. Rutter (ed.): Dating Methods of Pleistocene Deposits and Their Problems. Geoscience Canada, Reprint Series 2, 1-7.

Ehlers, J. 1979: Fine gravel analysis after the Dutch method as tested out on Ristinge Klint, Denmark. Bulletin of the Geological Society of Denmark 27, 157-165.

Ehlers, J. 1992: Origin and distribution of red tills in North Germany. Sveriges Geologiska Undersökning Ca 81, 97-105.

Forman, S.L. 1990: Thermoluminescence properties of fjord sediments from Engleskbukta, western Spitsbergen, Svalbard: a new tool for deciphering depositional environment? Sedimentology, 37, 377-384.

Frenzel, P. 1993: Die Ostrakoden und Foraminiferen des pleistozänen Cyprinentons der Insel Rügen, NE-Deutschland, Ostsee. Meyniana 45, 65-85.

Gaigalas, A., Serebryanny, L. \& Valueva, M. 1992: Middle Valdaian forest environments at Birzai, northern Lithuania. Boreas 21, 289-293.

Grüger, E. 1989: Palynostratigrapny of the last interglacial / glacial cycle in Germany. Quaternary International 3/4, 69-79.

Haarsted, V. 1956: De Kvartærgeologiske og geomorfologiske forhold på Møn. Meddelelser fra dansk Geolgisk Forening 13, $124-126$.

Hamberg, L. 1989: The Weichselian white quartz sand deposits at Grønneksov and in the Ristinge Klint section: An example of periglacial aeolian sand sheet sediments. In K.S. Petersen, L.Aa Rasmussen, L. Hamberg, P. Konradi \& A.V. Nielsen (eds). Excursion Guide to the Quaternary Geology of the southwestern part of Denmark. Danmarks Geologiske Undersøgelse, Internal report 16, appendix 4.

Hansen, S. 1965: The Quaternary of Denmark. In K. Ramkama (ed.): The Quaternary vol. 1., Interscience Publishers, New York, 1-90.

Heiberg, E. O. 1991: Senglaciale søer. VARV 4, 104-118.

Hillefors, $\AA$. 1974: The stratigraphy and genesis of the Dösebacka and Ellesbo drumlins. Geologiska Föreningens i Stockholm Förhandlingar 96, 355-374.

Hillefors, $\AA$. 1986: The Dösebacka interstadials. Abstract for the 17 Nordiska Geologmötet 1986, Helsingfors Universitet, 54.

Hintze, V. 1937: Møens Klints Geologi. C. A. Reitzels forlag, København, $410 \mathrm{pp}$

Houmark-Nielsen, M. 1987: Pleistocene stratigraphy and glacial history of the central part of Denmark. Bulletin of the Geological Society of Denmark 36, 1-189.

Houmark-Nielsen, M. 1988: Nyt om sidste istid. Klintholm, et nyt kvartærgeologisk nøgleprofil i Østdanmark. VARV 4, 126-138.

Houmark-Nielsen, M. 1989: The last interglacial - glacial cycle in Denmark. Quaternary International 3/4, 31-39.

Houmark-Nielsen, M. 1990a: Kobbelgård og Kraneled ved Klintholm, nye noglelokaliteter på Østmøn. In K.S. Petersen, M. Houmark-Nielsen, E. Kolstrup \& C. Kronborg: Guide for NORDQUA i den centrale og sydlige del af Danmark, Senpleistocænet. Danmarks Geologiske Unders $\varnothing$ gelse, intern rapport nr. 48. Appendix 14, 9 pp.

Houmark-Nielsen, M. 1990b: Ristinge Klint. In K.S. Petersen, M. Houmark-Nielsen, E. Kolstrup \& C. Kronborg: Guide for NORDQUA i den centrale og sydlige del af Danmark, Senpleistocænet. Danmarks Geologiske Unders $\emptyset g e l s e$, intern rapport nr. 48. Appendix 11, 7 pp.

Houmark-Nielsen, M. \& Berthelsen, A. 1981: Kinetostratigraphic evaluation and presentation of glacial-stratigraphic data, with examples from northern Samsø, Denmark. Boreas $10,411-422$. 
Houmark-Nielsen, M. \& Kolstrup, E. 1981: A radiocarbon dated Weichselian sequence from Sejer $\varnothing$, Denmark. Geologiska Föreningen i Stockholm, Förhandlingar 103, 73-78.

Jensen, J. B. 1993: Late Weichselian deglaciation pattern in the southwestern Baltic: Evidence from glacial deposits off the island of Møn, Denmark. Bulletin of the Geological Society of Denmark 40, 314-331.

Knudsen, K. L. 1985: Foraminiferal faunas in Eemian deposits of the Oldenbüttel area near the Kiel Canal, Germany. Geologisches Jahrbuch A 86, 27-47.

Knudsen, K. L. 1991: Marine Eemian and Early Weichselian deposits in northern Denmark - A review of theforaminiferal stratigraphy. Quaternary International 10-12, 167-171.

Kolstrup, E. 1982: Late Glacial pollen diagrams from Hjelm and Draved mose (Denmark) with a suggestion of the possibility of drought during the Earlier Dryas. Review of Palaeobotany and Palynology 36, 35-63.

Kolstrup, E. 1991: A Late Pleistocene "initial" vegetation at Vrøgum, west Jutland (Denmark). Palaeogeography, Palaeoclimatology, Palaeoecology 88, 53-67.

Kolstrup, E. 1992: Danish pollen records radiocarbon-dated to between 50.000 and 57.000 yr BP. Journal of Quaternary Science 7, 163-172.

Kolstrup, E. \& Havemann, K. 1984: Weichselian Juniperus in the Frøslev alluvial fan (Denmark). Bulletin of the Geological Society of Denmark 32, 121-131.

Kolstrup, E. \& Houmark-Nielsen, M. 1991: Weichselian palaeoenvironments at Kobbelgård, Møn, Denmark. Boreas 20, 169-182.

Konradi, P. B. 1973: Foraminifera in some Danish glacial deposits. Bulletin of the Geological Institute, University of Uppsala, Special Issue 5, 173-175.

Konradi, P. B. 1976: Foraminifera in Eemian deposits at Stensigmose, southern Jutland. Danmarks Geologiske Unders $\varnothing$ gelse, II rk. 105, 57 pp.

Kristensen, P. 1993: Foraminifer- og ostrakodstratigrafi i Eem Interglacial $\mathbf{i}$ den vestlige del af $\emptyset$ stersøen. Unpublished M.Sc.-thesis, Geological Institute, University of Aarhus, 98 pp.

Kronborg, C. 1984: Absolut aldersdatering af kvartære aflejringer ved hjælp af thermoluminescens. Dansk Natur - Dansk Skole, Årsskrift 1984, 73-102.

Kronborg, C. \& Mejdahl, V. 1989: Thermoluminescence dating of Eemian and Early Weichselian deposits in Denmark. Quaternary International 3/4, 93-99.

Kronborg, C., Bender, H., Bjerre, R., Friborg, R., Jacobsen, H. O., Kristiansen, L., Rasmussen, P., Sørensen, P. R. \& Larsen, G. 1990: Glacial stratigraphy of East and Central Jutland. Boreas 19, 273-287.

Lagerlund, E. 1987: An alternative Weichselian glaciation model, with special reference to the glacial history of Skåne, South Sweden. Boreas. 16, 433-459.

Lagerlund, E. \& Houmark-Nielsen, M. 1993: Timing and pattern of the last deglaciation in the Kattegat region, southwest Scandinavia. Boreas 22, 337-347.

Lykke-Andersen, A.-L. 1982: Nogle nye C-14 dateringer fra Fldre Yoldia Ler i Hirtshals Kystklint. Dansk Geologisk Forening, Årsskrift for 1981, 119-121.

Madsen, V., Nordmann, V. \& Hartz, N. 1908: Eem-zonerne. Studier over Cyprinaleret og andre Eem Aflejringer i Danmark, Nord-Tyskland og Holland. Danmarks geologiske Undersøgelse II rk. 17, 302 pp.

Mangerud, J. 1989: Correlation of the Eemian and the Weichselian with deep sea oxygen isotope stratigraphy. Quaternary International $3 / 4,1-4$.
Miller, U. 1977: Pleistocene deposits of the Alnarp Valley, southern Sweden - Microfossils and their stratigraphical application. University of Lund, Department of Quaternary Geology, Thesis, 4, $116 \mathrm{pp}$.

Miller, G. H. \& Mangerud, J. 1986 Aminostratigraphy of European Marine Interglacial deposits. Quaternary Science Reviews $4,215-278$.

Mejdahl, V. 1988: The plateau method for dating partially bleached sediments by thermoluminescence. Quaternary Science Reviews 7, 347-348.

Mejdahl, V., Shlukov, A. I., Shakhovets, S. A., Voskovskaya, L. T. \& Lyashenko, H. G 1992: The effect of shallow traps: a possible source of error in TL dating of sediments. Ancient TL 10,2, 22-25.

Milthers, K. 1942: Ledeblokke og Landskabsformer i Danmark. Danmarks geologiske Undersøgelse. II rk. 69, $137 \mathrm{pp.}$

Nielsen, J. B 1987: Kvartærstratigrafiske observationer langs $\emptyset$ stsiden af Roskilde Fjord. Dansk geologisk Forening, Årsskrift for 1986, 41-47.

Nilsson, K. 1973: Glacialgeologiska problem i Sydvästskåne. University of Lund, Dept. of Quaternary Geology, Thesis 1, $20 \mathrm{pp}$.

Nordmann, V. 1928: La position stratigraphique des dépôts d'Eem. Danmarks geologiske Undersøgelse. II rk. 47, 81 pp.

Odgaard, B. 1982: A Middle Weichselian moss assemblage from Hirtshals, Danmark and some remarks on the environment 47.000 BP. Danmarks Geologiske Undersøgelse, Årbog 1981, 5-45.

Penny, D. 1989: Microfossils (foraminifera, ostracoda) from an Eemian (Last Interglaical) tidal flat sequence in south-west Denmark. Quaternary International 3/4, 85-91.

Petersen, K. S. 1984: Stratigraphical position of Weichselian Tills in Denmark. In K.-L. Königsson (ed.): Ten Years of Nordic Till Research. Striae 20, 75-78.

Petersen, K. S. \& Buch, A. 1974: Dislocated tills with Paleogene and Pleistocene marine beds. Tectonics, lithology, macro- and microfossils. Danmarks Geologiske Undersøgelse, Årbog 1973, 63-91.

Petersen, K. S. \& Kronborg, C. 1991: Late Pleistocene history of the inland glaciation in Denmark. In B. Frenzel (ed.): Klimagechichtliche Probleme der letzten 130000 Jahre. Paläoklimaforschung Bd. 1. Akadimie der Wissenschaften und der Literatur. Mainz. Gustav Fischer Verlag, Stuttgart, 331-342.

Postma, D. 1981: Formation of siderite and vivianite and the pore-water composition of a recent bog sediment in Denmark. Chemical Geology, 31, 225-244.

Ran, E. T. H. 1990: Dynamics of vegetation and environment during the Middle Pleniglacial in the Dinkel Valley (The Netherlands) Mededelingen Rijks Geologische Dienst 44, 3, 142-200.

Rosenqvist, I. Th. 1970: Formation of vivianite in Holocene clay sediments. Lithos 3, 327-344.

Stankowska, A. \& Stankowski, W. 1988: Vistulian ice sheet in the vicinity of Konin, Poland: A geomorphological, sedimentological and radiometric evidence. Geographia Polonica $55,141-150$.

Steinich, G. 1992: Die stratigraphische Einordnung der RügenWarmzeit. Zeitschrift geologisches Wissenschaften, $20(1 / 2)$, 125-154.

Steinmüller, A. 1967: Eine weichselszeitliche Schichtenfolge in der Goldenen Aue bei Nordhausen. Geologisches Jahrbuch 1, 373-394.

Ødum, H. 1933: Marint Interglacial på Sjælland, Hven, Møn og Rygen. Danmarks Geologiske Unders $\emptyset$ gelse IV rk. 4, 10, 5-23. 